\title{
When a Year Is Not Enough: Further Study of the Seasonality of Planktonic Protist Communities Structure in an Ice-Free High Arctic Fjord (Adventfjorden, West Spitsbergen)
}

\author{
Anna Maria Dąbrowska ${ }^{1, * \mathbb{C}}$, Józef Maria Wiktor ${ }^{1}{ }^{\mathbb{C}}$, Józef Mikołaj Wiktor, Jr. ${ }^{1}$, Svein Kristiansen ${ }^{2}$, Anna Vader ${ }^{3}$ \\ and Tove Gabrielsen ${ }^{3}$ \\ 1 Department of Marine Ecology, Institute of Oceanology Polish Academy of Sciences, Powstańców Warszawy \\ 55, 81-712 Sopot, Poland; wiktor@iopan.gda.pl (J.M.W.); wiktor_jr@iopan.gda.pl (J.M.W.J.) \\ 2 Department of Arctic and Marine Biology, The Arctic University of Norway (UiT), 9037 Tromsø, Norway; \\ svein.kristiansen@uit.no \\ 3 Department of Arctic Biology, The University Centre in Svalbard (UNIS), 9171 Longyearbyen, Norway; \\ Anna.Vader@unis.no (A.V.); tove.gabrielsen@unis.no (T.G.) \\ * Correspondence: dabrowska@iopan.gda.pl; Tel.: +48-58-551-72-81
}

Citation: Dąbrowska, A.M.; Wiktor, J.M.; Wiktor, J.M., Jr.; Kristiansen, S.; Vader, A.; Gabrielsen, T. When a Year Is Not Enough: Further Study of the Seasonality of Planktonic Protist Communities Structure in an Ice-Free High Arctic Fjord (Adventfjorden, West Spitsbergen). Water 2021, 13, 1990. https://doi.org/10.3390/ w13141990

Academic Editors: Javier Gilabert, Piotr Margonski and Zita Gasiunaite

Received: 8 June 2021

Accepted: 18 July 2021

Published: 20 July 2021

Publisher's Note: MDPI stays neutra with regard to jurisdictional claims in published maps and institutional affiliations.

Copyright: (c) 2021 by the authors. Licensee MDPI, Basel, Switzerland. This article is an open access article distributed under the terms and conditions of the Creative Commons Attribution (CC BY) license (https:/ / creativecommons.org/licenses/by/ $4.0 /)$.

Abstract: As a contribution to understanding the ecological framework of protistan seasonal succession patterns, we present the weekly-to-monthly (January-October) light microscopy-based study of nano- and microplanktonic protist communities of Adventfjorden waters in 2013. In general, protist dynamics corresponded to the classic paradigm for the Arctic ice-free waters with extremely low abundance and diversity in winter, with the main abundance and chlorophyll-a peak in April-May, followed by a diverse but low abundant community during summer/autumn. However, the reference of the obtained data to the previously conducted year-round research in 2012 allows us to observe substantial variability in seasonal patterns between the two consecutive years. The most striking difference concerned the spring bloom composition and abundance, with clear domination of Phaeocystis pouchetii in Atlantified fjord waters in 2012 and Bacillariophyceae-dominated (mainly Fragilariopsis, Thalassiosira nordenskioeldii, and, in a lesser extent, also Pseudo-nitzschia seriata) bloom in 2013 when local water prevailed. On the other hand, a surprisingly high share of spring bloom taxa persisted throughout the summer/autumn of 2013 when they co-occurred with typical summer taxa (dinoflagellates and other small flagellates). Their extended growth could, at least in part, result from scarce Ciliophora throughout the season, which, in turn, can be attributed to the high grazing pressure of very numerous meroplankton and mesozooplankton. In light of this, our results may be relevant in discussions proposed for the West Spitsbergen waters link between the Atlantic water inflow and the spring bloom composition, as well as its further progression in the productive season. They also highlight the strong need for further high-resolution monitoring of annual plankton cycles and great caution when looking for phenological patterns within a single year or when interpreting short-term data.

Keywords: planktonic protists; seasonal dynamics; abundance; Adventfjorden; West Spitsbergen

\section{Introduction}

Protist communities, particularly at high latitudes, show strong seasonal shifts in qualitative and quantitative compositions associated with light conditions, ice cover, water masses, nutrient availability and grazing pressure. Protists are critically important for the functioning of marine ecosystems as primary producers and consumers of carbon and maintainers of biogeochemical cycles [1]. Despite their unquestionable importance, little is known about their seasonal dynamics in the Arctic waters [2]. This is primarily because most studies have been limited mainly to snapshots of the plankton ecosystem during either spring or summer sampling campaigns [3]. Thus, it is clear that more high-resolution 
and especially in-situ studies are necessary to better understand the bloom dynamics and their further evolution throughout the production season.

The knowledge gap for the West Spitsbergen fjords is the most apparent for Isfjorden $\left(78^{\circ} \mathrm{N}\right)$ [4]. It is a unique place to study the Arctic marine ecosystem since it is influenced by the West Spitsbergen Current, an extension of the North Atlantic Current system that transports warm, saline Atlantic water (AW) along the western Spitsbergen coast and by colder, less saline Arctic water [5]. Its side branches (such as the Adventfjorden located on the southern shore of Isfjorden) can also experience strong freshwater inputs from glacial rivers every summer and autumn [6]. These inputs bring sediments, nutrients and organic matter across the land-ocean interface, with a range of implications for coastal ecosystems and biogeochemical cycling [7]. In combination with extreme Arctic light conditions, the periodic changes in hydrography make this site well suited for studying environmental variability on marine organisms. For this reason, Isfjorden is recognised as a representative system to follow ocean climate change in the Arctic Ocean and, in that way, be used as an indicator for climate change in its Eurasian part [8].

Despite its relatively high potential for climatic research and logistical availability (close to Longyearbyen, the largest settlement in Svalbard), only a few protists studies were published for Isfjorden [4,9-14]. In this respect, the Kongsfjorden $\left(79^{\circ} \mathrm{N}\right)$ communities are better known, and their sizeable inter-annual variability with no apparent long-term trend, potentially steered by AW inflows, has been already shown (e.g., [15-17]). However, it is still unclear how the oceanographic conditions shape annual protistan production and biodiversity, and what the consequences are for the marine ecosystem [3].

The presented data are the results of the continuation of the first multidisciplinary, high-resolution seasonal study of the plankton ecosystem in Isfjorden-Adventfjorden waters (IsA time-series station; https:/ / research.unis.no/isa/ (accessed on 29 June 2021)), which includes already published works on the microbial eukaryote community $[11,12,18]$, the nano- and microplanktonic protists ([13]; year-round research in 2012), the meroplankton community [19] and the vertical flux of particulate matter [20]. The goal was to investigate further the seasonal (winter to autumn 2013) changes in the planktonic protist community structure in the Adventfjorden, the ice-free branch of Isfjorden, to fill the evident gap in the existing data. Furthermore, we specifically address the identification of possible differences and similarities in protist dynamics between the two consecutive years with different oceanographic conditions (2012 vs. 2013) to contribute to the discussion on the already proposed impact of AW waters on West Spitsbergen protists phenology.

\section{Materials and Methods}

2.1. Study Area

\subsubsection{Isfjorden}

Isfjorden $\left(78^{\circ} 70^{\prime} \mathrm{N}-78^{\circ} 27^{\prime} \mathrm{N}\right)$ is the largest fjord in the Svalbard archipelago. Due to the wide (approximately $10 \mathrm{~km}$ ) and deep (455 m) sill-less mouth, it is open to the oceanshelf transport and exchange (Figure 1). In some years, the ocean waters have so intensely affected the shelf that they fill the main pool of the fjord [5]. The intensity of the water advection into Isfjorden and the degree of mixing with local waters vary inter-annually and mainly depend on the fjord water's hydrography [21] and the wind activity both locally and on the West Spitsbergen Shelf [22]. In Isfjorden, the AW is partially transformed by mixing with local water, and then it flows out the fjord along the northern shore [23]. Constant ice cover is dominant in most of the inner bays of the northern and eastern parts of Isfjorden during a significant portion of the year (mid-November to July, [24]). Other parts of Isfjorden only have periodic drifting ice, and the amount is dependent on air and sea dynamic conditions (i.e., wind, currents, [24]). 


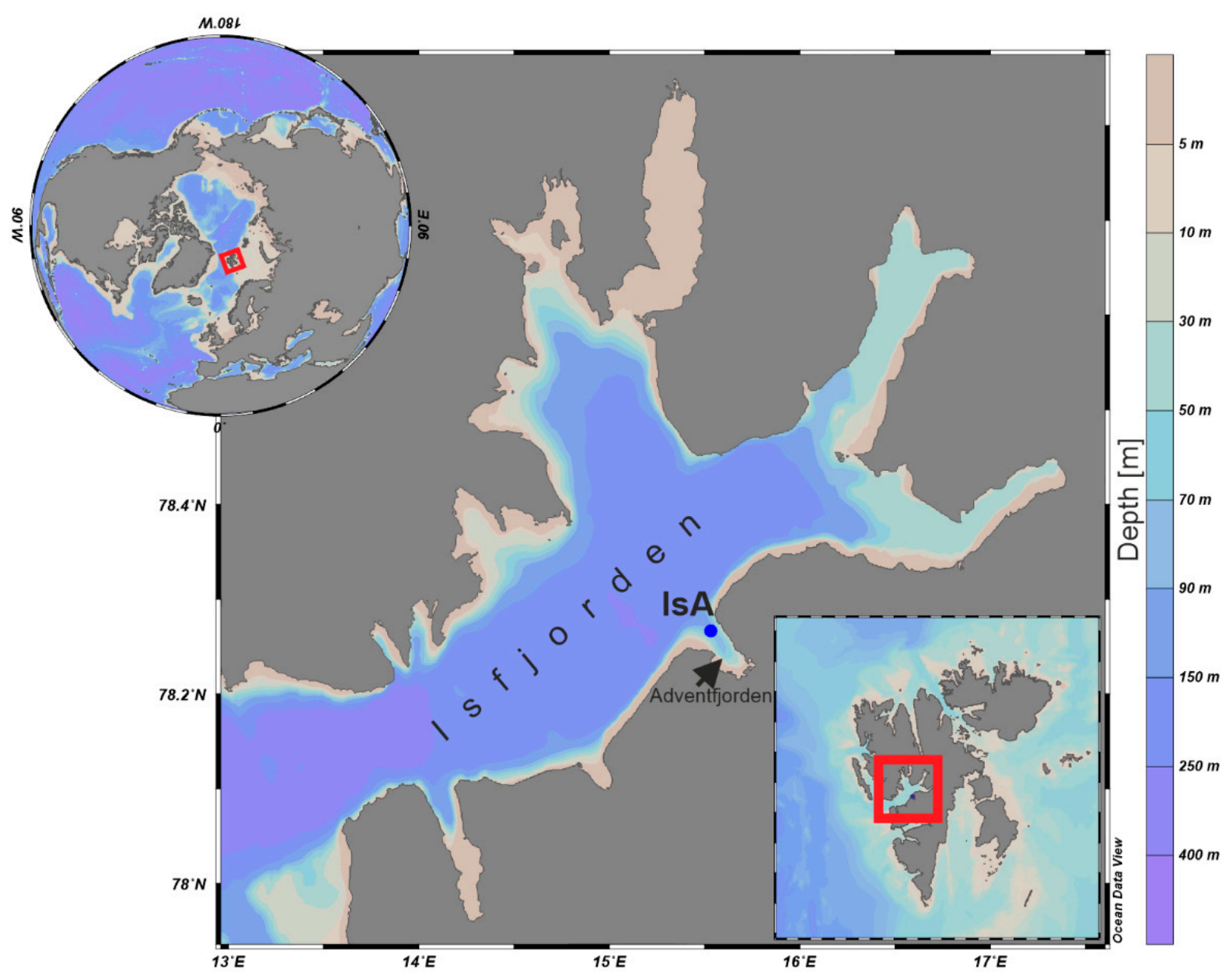

Figure 1. Water sampling site (IsA station) in Isfjorden (Svalbard). Water depth [m] for Isfjorden is indicated by the colour scale bar.

\subsubsection{Adventfjorden}

Adventfjorden is a small (approximately $8 \mathrm{~km}$ in length and $3 \mathrm{~km}$ in width), openended southeastern branch of Isfjorden (Figure 1). Most of the Adventfjorden basin's depth exceeds $50 \mathrm{~m}$, with depths greater than $100 \mathrm{~m}$ in the outer areas. In the summer and autumn (June-October), two rivers, Longyearelva and Adventelva (the latter one of the largest rivers of the Svalbard archipelago), supply large amounts of fresh water and sediment load to the fjord, affecting the optical properties of the seawater [25]. Due to climate-driven changes in wind stress patterns over the Fram Strait and increased transport of warm AW into Isfjorden, ice-free conditions throughout winter have tended to prevail over the last decade, with the fjord remaining mostly open since 2005 [22].

\subsection{Data Collection}

Samplings were conducted at weekly-to-monthly intervals at the mouth of Adventfjorden (an 85-m-deep IsA time-series station), close to Longyearbyen $\left(78^{\circ} 16^{\prime} \mathrm{N}, 15^{\circ} 32^{\prime} \mathrm{E}\right.$; Figure 1, Table 1, sampling dates $(\mathrm{n}=27))$. During the bloom period (April-June), samples were collected with a higher frequency. The ice-free conditions allowed boat-based sampling throughout the campaign. A vertical conductivity-temperature-depth (CTD) profiler was obtained at each sampling event using an SD204 CTD probe (SAIV A/S, Bergen, Norway). Based on the CTD measurements, we calculated the seawater density (sigma- $t$ ) using the formula developed by Mamaev [26]. Light measurements were conducted with a cosine PAR (photosynthetically active radiation) sensor and an LI-1000 DataLogger device (Li-Cor, Inc., Lincoln, NE, USA). Seawater was sampled using a 10-L Niskin bottle (KC Denmark) at four 
standard depths $(5 \mathrm{~m}, 15 \mathrm{~m}, 25 \mathrm{~m}$ and $60 \mathrm{~m})$. Samples used for the protist community and chlorophyll- $a$ analyses were collected from 10 January to 9 October, whereas samples for nutrient analyses were collected until mid-June.

Table 1. Overview of sampling dates and environmental data (mean values and range: minimum and maximum) collected at the IsA station. Abbreviations: W-winter, ES-early spring, S-spring, S/A-summer/autumn, EZ-euphotic zone extension.

\begin{tabular}{|c|c|c|c|c|c|c|c|c|c|c|c|c|}
\hline \multirow[t]{2}{*}{ Date } & \multirow[t]{2}{*}{ Season } & \multicolumn{2}{|c|}{ Temperature $\left[{ }^{\circ} \mathrm{C}\right]$} & \multicolumn{2}{|c|}{ Salinity } & \multicolumn{2}{|c|}{$\begin{array}{c}\mathrm{NO}_{3}^{-}+\mathrm{NO}_{2}^{-} \\
{\left[\mathrm{mmol} \mathrm{m} \mathbf{m}^{-3}\right]}\end{array}$} & \multicolumn{2}{|c|}{$\begin{array}{c}\mathrm{PO}_{4}^{3-} \\
{\left[\mathrm{mmol} \mathrm{m}^{-3}\right]}\end{array}$} & \multicolumn{2}{|c|}{$\underset{\left[\mathrm{mmol} \mathrm{m}^{-3}\right]}{\mathrm{Si}(\mathrm{OH})_{4}}$} & \multirow[t]{2}{*}{$\begin{array}{l}\mathrm{EZ} \\
{[\mathrm{m}]}\end{array}$} \\
\hline & & Mean & Range & Mean & Range & Mean & Range & Mean & Range & Mean & Range & \\
\hline 10.01 .2013 & $\mathrm{~W}$ & 1.55 & $1.543-1.552$ & 34.7 & $34.666-34.667$ & - & - & - & - & - & - & - \\
\hline 23.01.2013 & W & 1.23 & $0.923-1.354$ & 34.7 & $34.73-34.76$ & 7.03 & $5.49-9.72$ & 0.54 & $0.50-0.65$ & 3.52 & $2.54-4.88$ & - \\
\hline 30.01 .2013 & W & 1.08 & $1.067-1.087$ & 34.8 & $34.74-34.80$ & 5.9 & $4.35-8.64$ & 0.52 & $0.49-0.61$ & 2.84 & $1.94-4.48$ & - \\
\hline 05.02 .2013 & W & 0.53 & $0.41-0.83$ & 34.7 & $34.68-34.76$ & 5.99 & $4.30-9.17$ & 0.54 & $0.45-0.66$ & 3.07 & $2.05-4.89$ & - \\
\hline 11.02 .2013 & W & - & - & - & - & 6.53 & $5.40-7.39$ & 0.68 & $0.51-1.06$ & 2.8 & $1.97-4.08$ & - \\
\hline 19.02 .2013 & W & 0.93 & $0.93-0.94$ & 34.8 & $34.81-34.85$ & 7.66 & $6.65-8.44$ & 0.57 & $0.54-0.62$ & 3.9 & $2.97-4.42$ & - \\
\hline 01.03 .2013 & ES & -0.57 & $-0.82--0.30$ & 34.7 & $34.64-34.77$ & 5.94 & $4.29-8.06$ & 0.53 & $0.45-0.60$ & 2.24 & $1.52-3.53$ & 40 \\
\hline 15.03.2013 & ES & -0.32 & $-0.36--0.29$ & 34.8 & $34.78-34.79$ & 6.67 & $5.06-8.96$ & 0.51 & $0.42-0.58$ & 2.92 & $2.11-4.65$ & - \\
\hline 20.03.2013 & ES & -0.31 & $-0.47--0.25$ & 34.8 & $34.77-34.79$ & 4.64 & $4.06-5.80$ & 0.47 & $0.44-0.49$ & 2.33 & $1.81-3.48$ & - \\
\hline 05.04 .2013 & ES & -0.37 & $-0.61--0.29$ & 34.8 & $34.83-34.86$ & 6.29 & $3.92-8.37$ & 0.51 & $0.42-0.61$ & 3.38 & $1.78-4.84$ & - \\
\hline 11.04.2013 & ES & -0.61 & $-0.64--0.53$ & 34.8 & $34.75-34.80$ & 5.51 & $3.74-8.09$ & 0.49 & $0.43-0.60$ & 2.77 & $1.69-4.49$ & - \\
\hline 19.04.2013 & $S$ & -0.57 & $-0.94--0.35$ & 34.8 & $34.77-34.81$ & 8.62 & $6.27-10.83$ & 0.81 & $0.64-0.96$ & 4.49 & $2.57-5.84$ & - \\
\hline 24.04 .2013 & $S$ & -0.97 & $-1.02--0.94$ & 34.4 & $34.35-34.45$ & 0.73 & $0.56-1.18$ & 0.2 & $0.15-0.26$ & 1.39 & $1.14-1.61$ & 15 \\
\hline 02.05 .2013 & S & -0.32 & $-0.54-0.04$ & 34.6 & $34.50-34.66$ & 4.27 & $3.21-5.45$ & 0.35 & $0.27-0.45$ & 1.38 & $0.87-2.35$ & - \\
\hline 10.05.2013 & $S$ & - & $\begin{array}{c}0.01-0 \\
-\end{array}$ & - & $\begin{array}{c}- \\
-\end{array}$ & 1.06 & $0.12-3.33$ & 0.13 & $0.06-0.28$ & 1.25 & $1.03-1.37$ & - \\
\hline 15.05.2013 & $S$ & -0.2 & $-0.23--0.18$ & 34.4 & $34.34-34.50$ & 0.28 & $0-1.11$ & 0.08 & $0.04-0.13$ & 1 & $0.15-1.39$ & 30 \\
\hline 24.05 .2013 & $S$ & -0.06 & $-0.26-0.21$ & 34.5 & $34.25-34.68$ & 1.55 & $0.08-3.17$ & 0.22 & $0.09-0.40$ & 0.35 & $0.20-0.61$ & - \\
\hline 30.05 .2013 & $S$ & 0.56 & $0.28-0.85$ & 34.4 & $34.32-34.45$ & 0.49 & $0.25-0.88$ & 0.05 & $0.03-0.07$ & 1.06 & $0.75-1.19$ & 20 \\
\hline 05.06 .2013 & $\mathrm{~S} / \mathrm{A} *$ & 0.9 & $0.26-1.53$ & 34.2 & $33.94-34.39$ & 0.71 & $0.17-1.81$ & 0.08 & $0.06-0.11$ & 0.14 & $0.11-0.22$ & 6 \\
\hline 12.06 .2013 & $\mathrm{~S} / \mathrm{A}$ & 1.66 & $0.46-2.09$ & 34.2 & $34.08-34.38$ & 0.28 & $0.15-0.54$ & 0.07 & $0.05-0.10$ & 0.49 & $0.12-1.01$ & 45 \\
\hline 19.06 .2013 & $\mathrm{~S} / \mathrm{A}$ & 1.98 & $0.19-2.81$ & 34.1 & $33.87-34.43$ & - & - & - & - & - & - & 20 \\
\hline 10.07 .2013 & $\mathrm{~S} / \mathrm{A}$ & 4.23 & $1.57-6.31$ & 33.2 & $31.43-34.37$ & - & - & - & - & - & - & - \\
\hline 24.07.2013 & $\mathrm{S} / \mathrm{A}$ & 3.96 & $0.97-6.46$ & 33.3 & $31.67-34.46$ & - & - & - & - & - & - & 15 \\
\hline 07.08 .2013 & $\mathrm{~S} / \mathrm{A}$ & - & - & - & - & - & - & - & - & - & - & 20 \\
\hline 22.08 .2013 & $\mathrm{~S} / \mathrm{A}$ & 5.32 & $2.90-6.54$ & 33.2 & $31.96-34.43$ & - & - & - & - & - & - & 20 \\
\hline 08.09 .2013 & $\mathrm{~S} / \mathrm{A}$ & 5.66 & $4.31-6.15$ & 33.3 & $32.32-34.53$ & - & - & - & - & - & - & 20 \\
\hline 09.10 .2013 & $\mathrm{~S} / \mathrm{A}$ & 4.84 & $4.64-5.19$ & 34.3 & $34.23-34.45$ & - & - & - & - & - & - & - \\
\hline
\end{tabular}

* The summer and autumn data were combined due to less frequent sampling in these periods.

\subsubsection{Nutrients}

Subsamples of $200 \mathrm{~mL}$ volume were frozen in acid-washed plastic bottles and analysed within nine months. The nitrate plus nitrite $\left(\mathrm{NO}_{3}{ }^{-}+\mathrm{NO}_{2}{ }^{-}\right)$, phosphate $\left(\mathrm{PO}_{4}{ }^{3-}\right)$ and silicic acid $\left(\mathrm{Si}(\mathrm{OH})_{4}\right)$ concentrations $\left[\mathrm{mmol} \mathrm{m}^{-3}\right]$ were measured with a Flow Solution IV Analyser (OI Analytical, College Station, TX, USA) calibrated with reference seawater (Ocean Scientific International Ltd., Havant, UK). The detection limits were $0.02 \mathrm{mmol} \mathrm{m}^{-3}$ for nitrate plus nitrite, $0.01 \mathrm{mmol} \mathrm{m}^{-3}$ for phosphate and $0.07 \mathrm{mmol} \mathrm{m}^{-3}$ for silicic acid.

\subsubsection{Chlorophyll- $a$}

Subsamples $(250 \mathrm{~mL}-400 \mathrm{~mL})$ were analysed in triplicate, as described by HolmHansen and Riemann [27]. They were filtered through Whatman GF/F filters (nominal pore size of $0.7 \mu \mathrm{m}$ ), folded, wrapped in aluminium foil and immediately frozen at $-80^{\circ} \mathrm{C}$. Pigment extraction was performed in $10 \mathrm{~mL}$ of methanol for $20-24 \mathrm{~h}$ in the cold $\left(4^{\circ} \mathrm{C}\right)$ dark place no later than nine months after sampling. The chlorophyll- $a$ concentration $\left[\mathrm{mg} \mathrm{m}^{-3}\right]$ was measured with a Turner Design AU-fluorometer (calibrated with pure chlorophyll- $a$, Sigma S6144).

\subsubsection{Planktonic Protists}

Subsamples of $200 \mathrm{~mL}$ were immediately fixed with an acidic Lugol's solution for $24 \mathrm{~h}$ and then with borax-buffered formaldehyde. Both fixatives were added to a final concentration of $2 \%$. Qualitative and quantitative analyses were conducted using protocols described by Utermöhl [28] and modified by Edler [29] no later than six months after collection. A subsample of 10-50 mL was placed in a Utermöhl settling chamber for $24 \mathrm{~h}$. Settled protists were counted under an inverted microscope equipped with phase and interference contrasts (Nikon Eclipse TE-300). Microplankton (>20 $\mu \mathrm{m}$ ) was enumerated 
from the entire chamber surface at $100 \times$ magnification. Nanoplanktonic protists $(3-20 \mu \mathrm{m})$ were counted at $400 \times$ magnification by moving the field of view along the length of three transverse transects. We counted up to 50 specimens for the most numerous taxa, and the number of fields of view was considered individually. The taxa were identified to the lowest possible taxonomic level following the World Register of Marine Species (WoRMS, http:/ / www.marinespecies.org (accessed on 1 May 2013-30 June 2014)). Small $(\leq 10 \mu \mathrm{m})$ indeterminate flagellates were classified as mono- or biflagellates and categorised as Flagellate indet.; microbial eukaryotes of size 0.45 to $10 \mu \mathrm{m}$ were extensively studied during the IsA campaign and reported separately by Marquard et al. [11].

\subsection{Data Analysis}

All contouring of hydrographical, hydrochemical and biological data for vertical sections was done using SURFER (version 10.0, Golden Software) and Kriging interpolation, which estimates values throughout a specified region based on the available data (marked on the graphs). Water mass classifications were made using Ocean Data View (version 5.3.0) based on categories specific to Isfjorden [5]: surface waters $(\mathrm{SW})=\mathrm{Sal}<34, \mathrm{~T}>1^{\circ} \mathrm{C}$, intermediate waters $(\mathrm{IW})=34<\mathrm{Sal}<34.7, \mathrm{~T}>1{ }^{\circ} \mathrm{C}$, Atlantic waters $\left.(\mathrm{AW})=\mathrm{Sal}>34.9, \mathrm{~T}>3^{\circ} \mathrm{C}\right)$, transformed Atlantic water $(\mathrm{TAW})=\mathrm{Sal}>34.7, \mathrm{~T}>1{ }^{\circ} \mathrm{C}$, Arctic water $(\mathrm{ArW})=34.4<\mathrm{Sal}<34.8,-1.5>\mathrm{T}<1{ }^{\circ} \mathrm{C}$, winter cooled water $(\mathrm{WCW})=\mathrm{Sal}>34.74, \mathrm{~T}<-0.5^{\circ} \mathrm{C}$ ) and local water $(\mathrm{LW})=\mathrm{T}<1{ }^{\circ} \mathrm{C}$. The total chlorophyll- $a$ concentrations and abundance (per cubic metre) were averaged for the 5-60 $\mathrm{m}$ water column. The relative abundances [\%] were presented for the major protist groups (classes where possible), which constituted at least $10 \%$ of the total abundance per cubic metre in at least $10 \%$ of the samples, as adopted in Kubiszyn et al. [13]. We used R (version 3.4.3, [30]) and the Vegan 2.4-3 library Community Ecology Package for R [31] for all statistical analyses. Non-metric multidimensional scaling (NMDS) ordination analysis based on the taxonomic composition data of the lowest possible taxonomic level expressed as log10transformed abundance per square metre was used to explore the variability in the protist community structure (the time trajectory was added to the plot). Bray-Curtis dissimilarity was used as the distance metric. The associations of the protists to their seasonal changes are presented as a heat map of their contributions to the total abundance per square metre. Only taxa with a contribution higher than $10 \%$ in any of the samples were selected. A Spearman rank correlation matrix between each taxon was calculated and converted to values representing a mutual association "distance" as follows: $\mathrm{d}=1-$ rho (the most correlated species presented the lowest distance, whereas non-correlated species had a distance close to 1). Completelinkage hierarchical clustering was applied to the "distance" matrix, and the results were used to order the species plotted on the heat map. The strength and direction of association between environmental and biological variables were measured using Spearman's rank-order correlation analyses. The correlation matrix was visualised using the R package "corrplot".

\section{Results}

\subsection{Hydrography}

The water column (down to a depth of $85 \mathrm{~m}$ ) properties varied substantially throughout the investigated period (Figure 2a). From January until late February, pulses of relatively warm $\left(<1.78^{\circ} \mathrm{C}\right)$ waters of Atlantic origin (TAW) were observed in Adventfjorden, alternating with local water throughout the entire winter (Figure 2b). During March to late April, these waters were substantially colder, saltier and denser $\left(-1.23\right.$ to $-0.05^{\circ} \mathrm{C}, 34.35$ to 34.87 , 27.64 to 28.41 , respectively) due to low air temperatures. At this time, WCW developed by convection of very cold and dense water produced by cooling. ArW carried by the inshore coastal current contributed to a relatively homogeneous water column at the IsA station. These waters were slightly warmer in May $\left(-1.04\right.$ to $\left.1.90^{\circ} \mathrm{C}\right)$, with the first signals of the presence of SW at the end of the month. During summer, the hydrographical parameters underwent intense and rapid changes. In June, the upper layer of the water column was predominated by warmer and fresher waters of SW and IW, which resulted in thermal stratification above depths of approximately $30 \mathrm{~m}$. From July to September, the water 
column stratification was much stronger and deeper, with markedly higher temperature $\left(4.25\right.$ to $7.28^{\circ} \mathrm{C}$ ) and lower salinity $(<34.00)$ down to approximately $50 \mathrm{~m}$ depth. This layer of variable thickness and temperature was highly influenced by SW, formed from glacial melt and river runoff. Beneath this, mixing between SW and the underlying Atlantic water produced IW. By the end of the summer, the temperature gradually decreased in the upper water column due to surface cooling, and a loss of thermal stratification was observed. At the end of October, the presence of relatively warm and saline TAW $\left(>4.80^{\circ} \mathrm{C},>34.70\right)$ below $40 \mathrm{~m}$ depth was noted in the fjord.

(a)

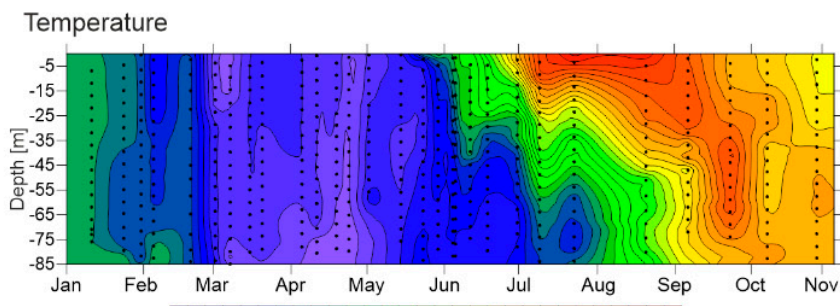

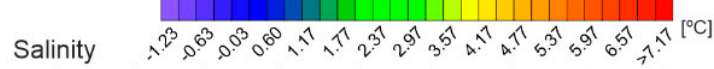
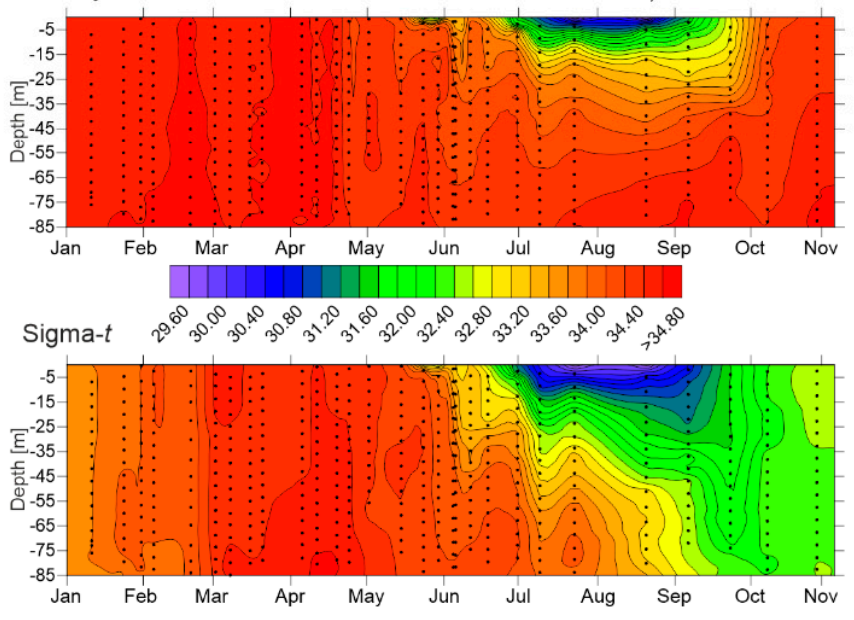

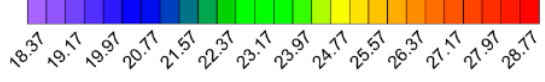

(b)

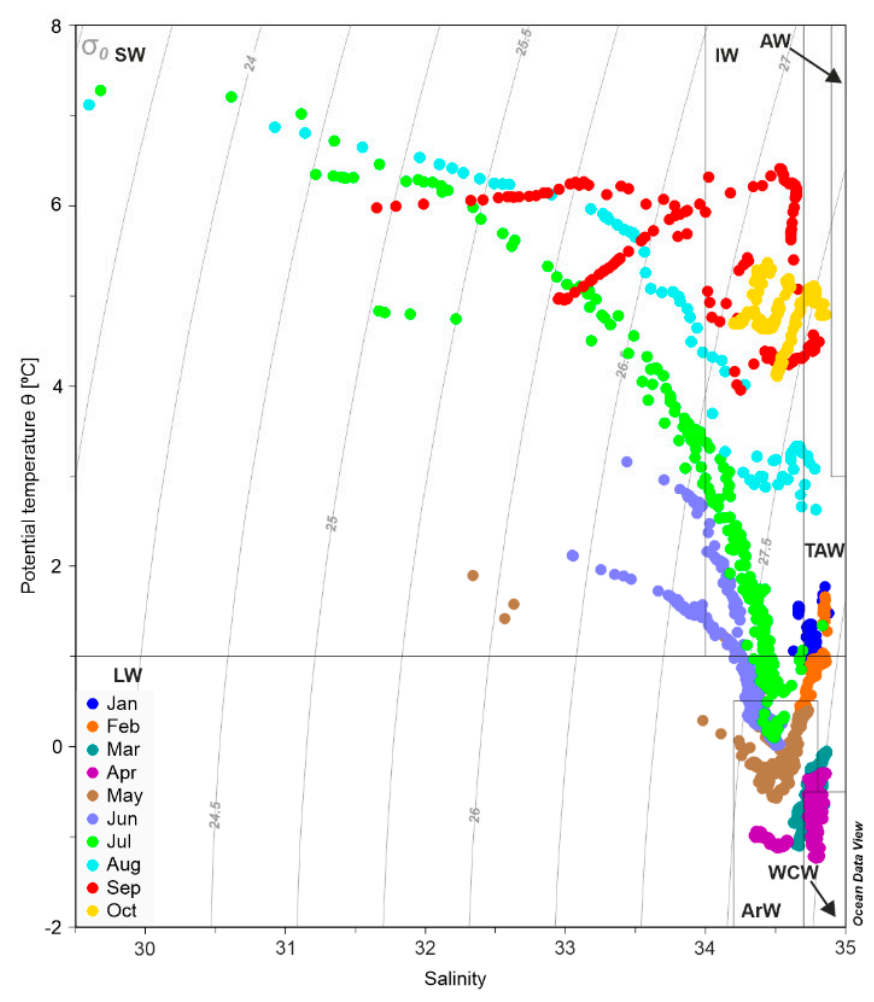

Figure 2. (a) Water temperature $\left[{ }^{\circ} \mathrm{C}\right]$, salinity and density (sigma- $t$ ) profiles at the IsA station in 2013 . The individual measurements are marked with dots (measurement marking frequency every $5 \mathrm{~m}$; similar symbols are used in Figure 3); (b) temperature-salinity (TS) diagram based on all conductivity-temperature-depth (CTD) profiles by sampling month. Abbreviations: SW—surface waters, IW—intermediate waters, AW-Atlantic waters, TAW—transformed Atlantic water, ArW-Arctic water, WCW-winter cooled water, LW-local water.

\subsection{Nutrients}

Strong seasonal fluctuations of hydrographic conditions were accompanied by high temporal variability in nutrients availability (Figure 3). The $\mathrm{PO}_{4}{ }^{3-}$ and $\mathrm{Si}(\mathrm{OH})_{4}$ concentrations followed the same general pattern observed for $\mathrm{NO}_{3}{ }^{-}+\mathrm{NO}_{2}{ }^{-}$. The highest nutrient concentrations were recorded in winter and early spring, with the maxima on 19 April (on average of $8.62 \mathrm{mmol} \mathrm{m}^{-3}$ for $\mathrm{NO}_{3}{ }^{-}+\mathrm{NO}_{2}{ }^{-}, 0.81 \mathrm{mmol} \mathrm{m}^{-3}$ for $\mathrm{PO}_{4}{ }^{3-}$, and $4.49 \mathrm{mmol} \mathrm{m}^{-3}$ for $\left.\mathrm{Si}(\mathrm{OH})_{4}\right)$. The highest molar ratio of $\mathrm{NO}_{3}{ }^{-}+\mathrm{NO}_{2}{ }^{-}$to $\mathrm{PO}_{4}{ }^{3-}$ (above 16:1; the Redfield's ratio, [32]) was found on 7 March throughout the water column (and later on 5 June at $5 \mathrm{~m}$ depth; data not shown). Along with the spring onset, the concentrations started to decrease rapidly. May exhibited the highest $\mathrm{NO}_{3}{ }^{-}+\mathrm{NO}_{2}{ }^{-}$ depletion, especially in the upper $25 \mathrm{~m}$ of the water column. To mid-May, concentrations were reduced to less than half the winter water values, followed by their almost complete 
absorption. Since June, $\mathrm{NO}_{3}{ }^{-}+\mathrm{NO}_{2}{ }^{-}$depletion was observed throughout the water column. Minimum values for $\mathrm{NO}_{3}{ }^{-}+\mathrm{NO}_{2}{ }^{-}$were found on $12 \mathrm{June}\left(0.28 \mathrm{mmol} \mathrm{m}{ }^{-3}\right)$, for $\mathrm{PO}_{4}{ }^{3-}$ on 30 May $\left(0.05 \mathrm{mmol} \mathrm{m}^{-3}\right)$ and for $\mathrm{Si}(\mathrm{OH})_{4}$ on $5 \mathrm{June}\left(0.14 \mathrm{mmol} \mathrm{m}^{-3}\right)$.

Nitrate plus nitrite

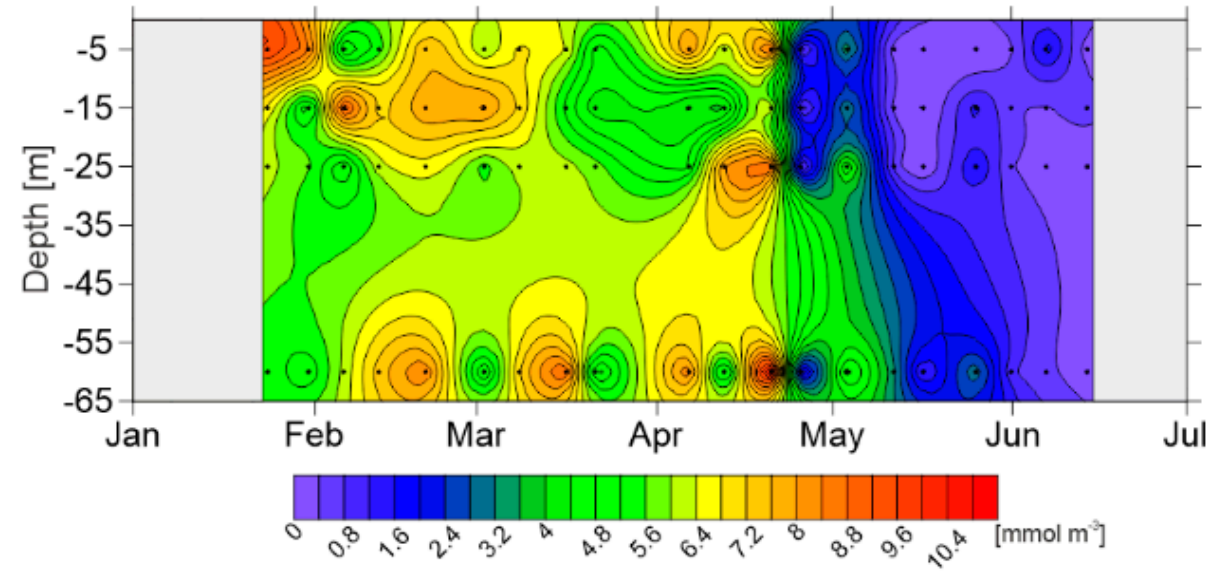

Phosphate

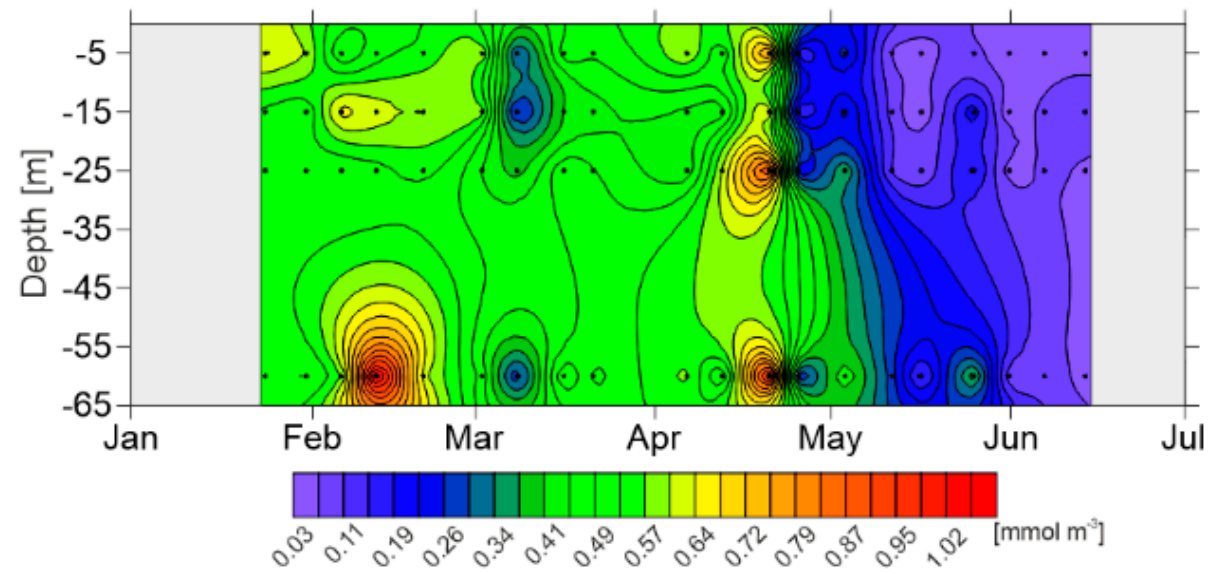

Silicic acid

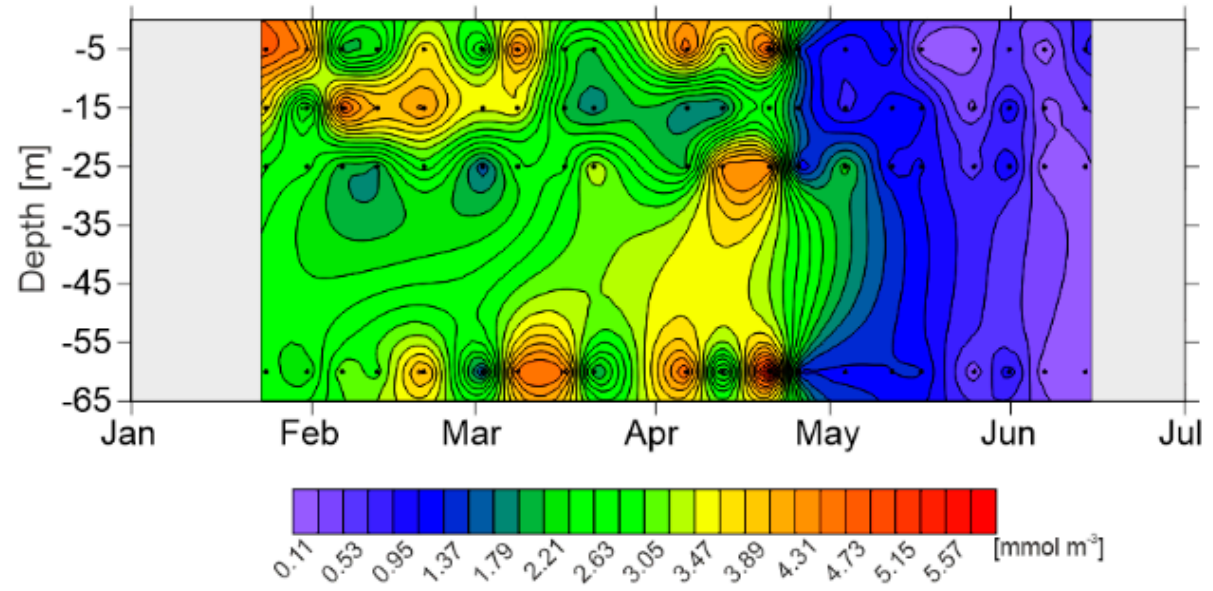

Figure 3. Nitrate plus nitrite, phosphate and silicic acid concentrations $\left[\mathrm{mmol} \mathrm{m}^{-3}\right]$ during the investigated period. The areas corresponding to the missing observations are also presented (as blank).

\subsection{Euphotic Zone Extension}

Although the limited number of measurements of euphotic zone thickness prevented us from accurately tracking the temporal changes in the extent of the euphotic zone, the collected data indicated its significant seasonal variability (Figure 4a). The euphotic zone 
depths varied irregularly from $6 \mathrm{~m}$ to $45 \mathrm{~m}$, with a maximum value on $12 \mathrm{June}$ and a minimum on 5 June. A single measurement in early spring (1 March, $40 \mathrm{~m}$ depth) indicated a substantial thickness of the euphotic zone at this time. Concomitant with the spring, its extension decreased, ranging from $15 \mathrm{~m}$ on 24 April to $30 \mathrm{~m}$ on 15 May. In summer/autumn, the euphotic zone depth at the IsA station was about $20 \mathrm{~m}$ on average.

(a)

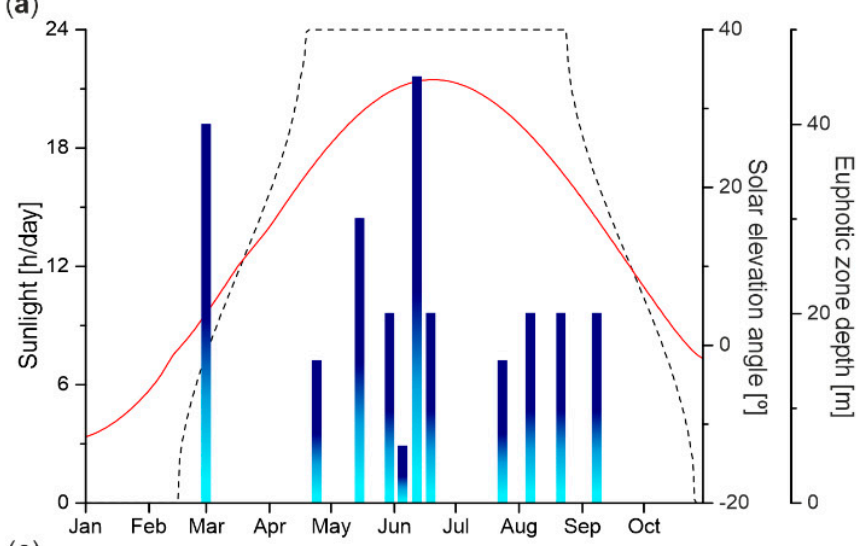

(c)

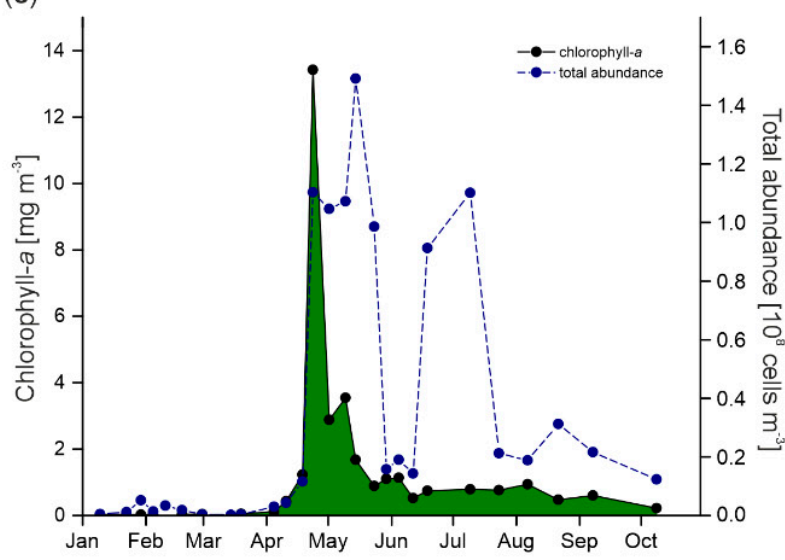

(b)

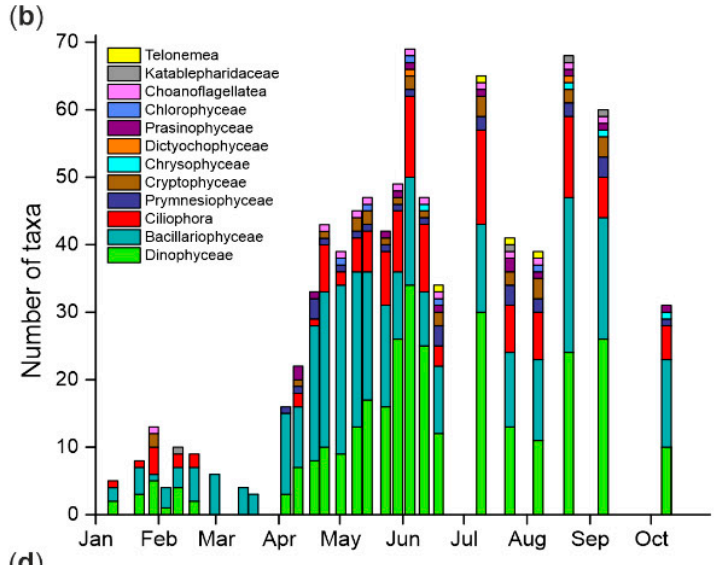

(d)

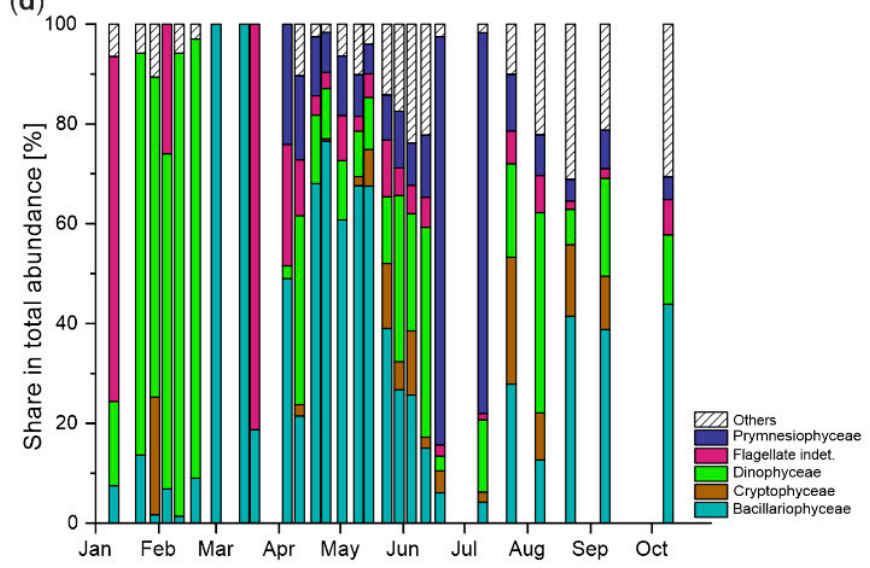

Figure 4. (a) Hours [h] of sunlight (black dashed line) and solar elevation angle $\left[{ }^{\circ}\right]$ per day (solid orange line) (in both cases, data were sourced from https:/ / www.unis.no/resources/weather-stations/; accessed on 10 March 2021), and depth of the euphotic zone [m] (gradient fill bars); (b) the total number of protists taxa (the groups were presented on bars in order from largest to smallest share in the total number of taxa; for groups with the same number of taxa, alphabetical order was applied); (c) chlorophyll- $a$ concentrations $\left[\mathrm{mg} \mathrm{m}^{-3}\right]$ (green-covered area) and total protist abundance $\left[10^{8} \mathrm{cells} \mathrm{m}^{-3}\right]$ (blue dashed line); (d) percent contribution of major groups to the total abundance at the IsA station during the investigated period.

\subsection{Protist Taxonomic Composition}

In 107 samples, 158 planktonic protist taxa were detected, of which 107 were identified to the species level (a list of taxa with their shares [\%] in the total abundance on a given day is available online as Supplementary File S1). The identified taxa belonged to 12 higher systematic groups, of which the vast majority (approximately $72 \%$ ) represented Bacillariophyceae and Dinophyceae, followed by Ciliophora (17\%) (Figure $4 b)$. The lowest taxonomic diversity was observed in winter and early spring (5-13 taxa per sample, mainly Bacillariophyceae and Dinophyceae). From April, the total number of taxa began to increase, and this trend with the predominant share of the two groups mentioned above continued until early June. The summer/autumn community constituted a mixture of different taxa with a substantial portion of Dinophyceae and Ciliophora. Although the number of taxa fluctuated throughout this period, a pronounced decline on 9 October was likely a symptom of approaching the end of the productive season. Additionally, besides the pool of identified taxa, indeterminate nanoplanktonic flagellates were common in the investigated material. Occasionally (mainly in winter and spring), resting stages 
of Chaetoceros furcillatus (Bacillariophyceae) and cysts of non-identified Chrysophyceae, Dinophyceae, and Ciliophora were observed.

\subsection{Protist Abundance and Chlorophyll-a}

After extremely low total abundance and low chlorophyll- $a$ concentrations in winter and early spring $\left(<0.05 \times 10^{8}\right.$ cells $\mathrm{m}^{-3}$ (primarily Dinophyceae), $<0.12 \mathrm{mg} \mathrm{m}^{-3}$, respectively), we observed a gradual increase in their values in the first two weeks of April (Figure 4c). The spring bloom occurred in the second half of April and lasted until late May. Its onset was manifested by an abrupt increase in the number of cells (almost 10fold between 19 April and 24 April, from $0.12 \times 10^{8}$ cells m ${ }^{-3}$ to $1.10 \times 10^{8}$ cells m$^{-3}$, primarily due to intensive growth of Bacillariophyceae, Figure $4 \mathrm{~d}$ ), also reflected in high chlorophyll- $a$ content (up to $13.42 \mathrm{mg} \mathrm{m}^{-3}$; a proxy for primary producers biomass). High protists abundance was maintained throughout May, even after a sudden drop of pigment concentration in early May ( 2.89 to $3.95 \mathrm{mg} \mathrm{m}^{-3}$ on 2 May and 10 May, respectively) and subsequent more gradual reduction to $0.89 \mathrm{mg} \mathrm{m}^{-3}$ at the end of the month. Low chlorophyll- $a$ concentrations, comparable to those observed earlier in winter, persisted until the end of the observational period with a minimum value on 9 October $\left(0.22 \mathrm{mg} \mathrm{m}^{-3}\right)$. In turn, a significant decrease in the protists number was observed in late May and early June, when the optical properties of the water column deteriorated, possibly due to the river runoff with suspended solids usually observed at this time of the year (Figure 4a; turbidity of the water column was not measured during this study). From mid-June to late July, the total abundance considerably increased to almost the spring bloom values. It was mainly due to high numbers of fixation-sensitive indeterminate Prymnesiophyceae, most likely of genus Chrysochromulina. Since the end of July, the total abundance remained relatively constant with a low level, up to $0.31 \times 10^{8}$ cells $^{-3}$. Initially, they were mainly flagellates (Dinophyceae and Cryptophyceae), followed by Bacillariophyceae from late August.

\subsection{Protist Community Development}

The NMDS ordination confirmed high temporal variability of the protist community composition throughout the investigated period (Figure 5). The Spearman rank test among environmental and biological data revealed that protists occurrence was negatively correlated with salinity and nutrients, suggesting that variations of both parameters were primarily responsible for the temporal changes of communities structure (Figure 6). The protist communities' composition demonstrated seasonal patterns (Figure 7). The winter community (10 January19 February) was composed primarily of nanoplanktonic representatives of the Gymnodinium genus (Gymnodinium galeatum, Gymnodinium spp. 5-20 $\mu \mathrm{m}$, Gymnodinium wulffii). Indeterminate biflagellates of size 3-7 $\mu \mathrm{m}$ were numerous at that time. In early spring (1 March-11 April), the community shifted toward domination of Bacillariophyceae (Thalassiosira spp. 10$30 \mu \mathrm{m}$, Navicula pelagica, Navicula transitans var. derasa and Gyrosigma fasciola, Pleurosigma sp.). The spring bloom community comprised ribbon-forming Bacillariophyceae of Fragilariopsis genus (F. cylindrus, F. cf. cylindrus, and F. oceanica), Pseudo-nitzschia seriata, as well as colonyforming prymnesiophyte Phaeocystis pouchetii. Both these groups were strongly correlated with chlorophyll- $a$ concentration (Figure 6). The summer/autumn community observed from 5 June to 9 October was principally formed by indeterminate Prymnesiophyceae and P. pouchetii, Cryptophyceae (Plagioselmis prolonga and Teleaulax sp.), various Dinophyceae of Gymnodinium genus (species observed in winter), and Bacillariophyceae of taxa constituting the residue of the previous season (Figure 7). The increasing share of Dinobryon balticum (Chrysophyceae), Dactyliosolen fragilissimus and Proboscia alata (both Bacillariophyceae) from 22 August indicated the transition of communities towards the autumn type. A few flagellates (Gymnodinium spp. 5-20 $\mu \mathrm{m}$, Gymnodinium galeatum, and biflagellates 3-7 $\mu \mathrm{m}$ ) constituted an almost year-round component of the protistan plankton. 


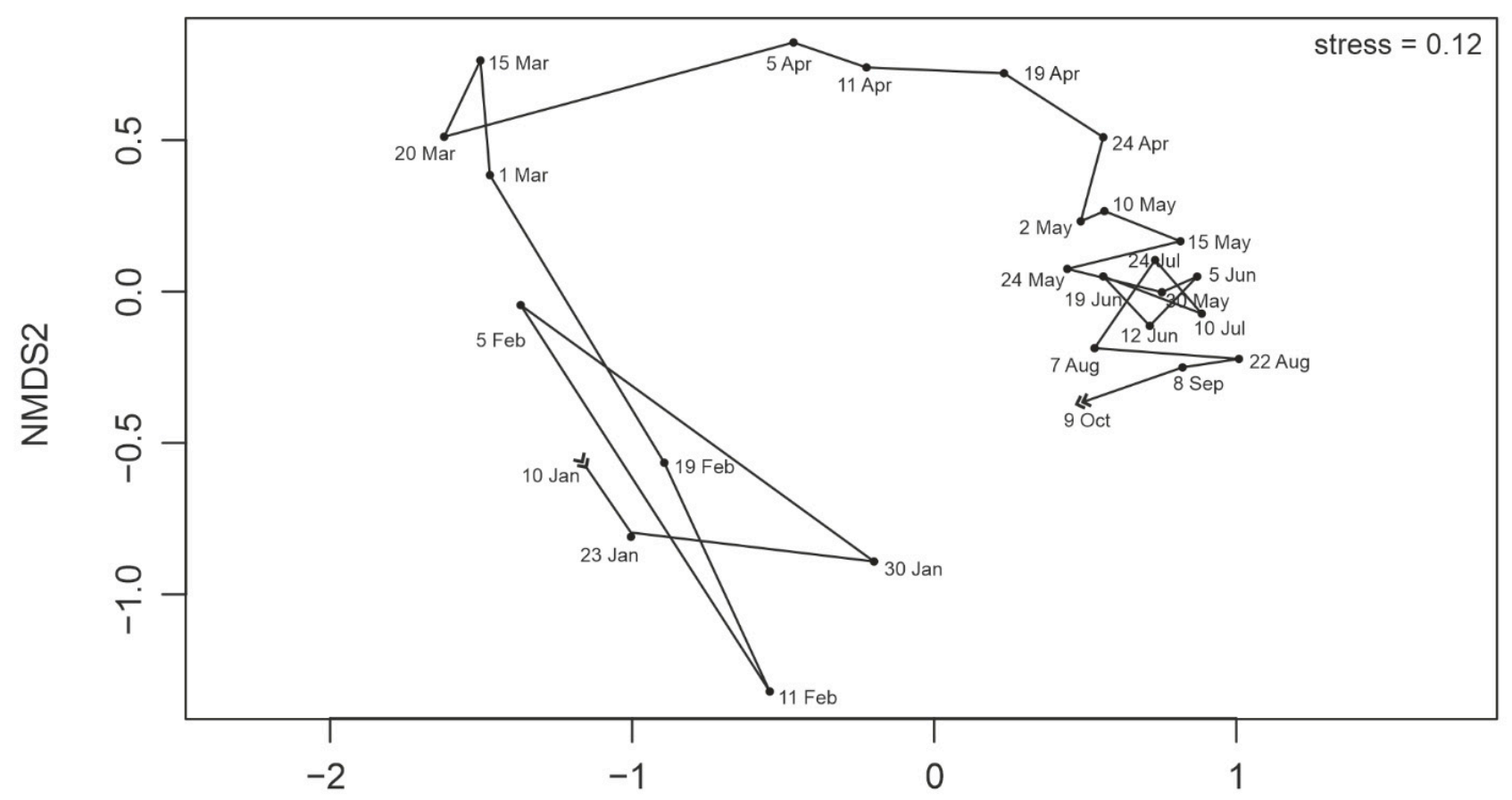

NMDS1

Figure 5. NMDS plot of Bray-Curtis dissimilarities between protist communities in 2013 (log-transformed abundance data). The beginning and end of the time trajectory are marked with an arrow.

(a)
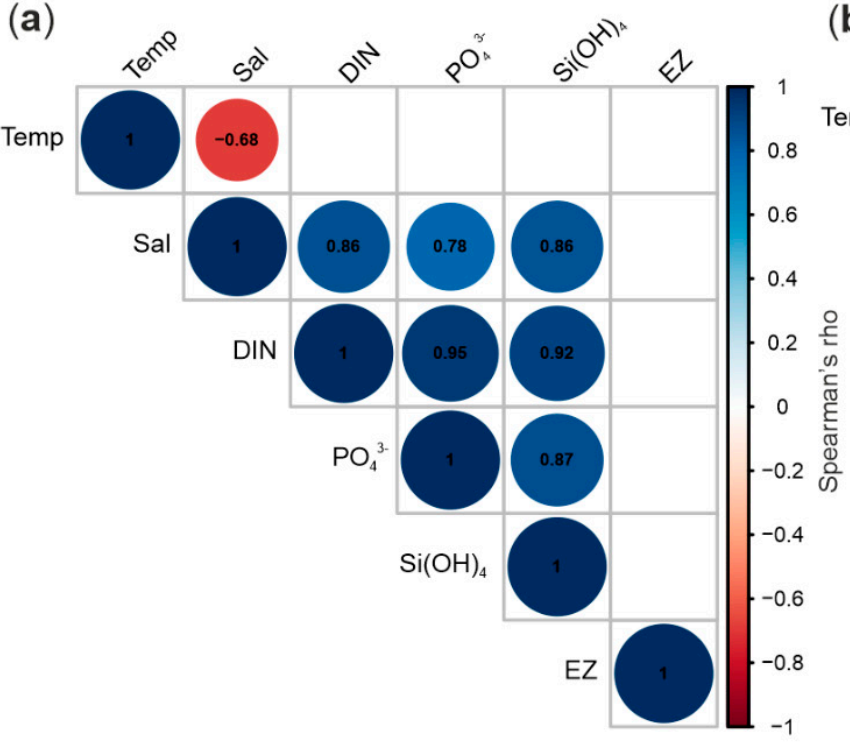

(b)

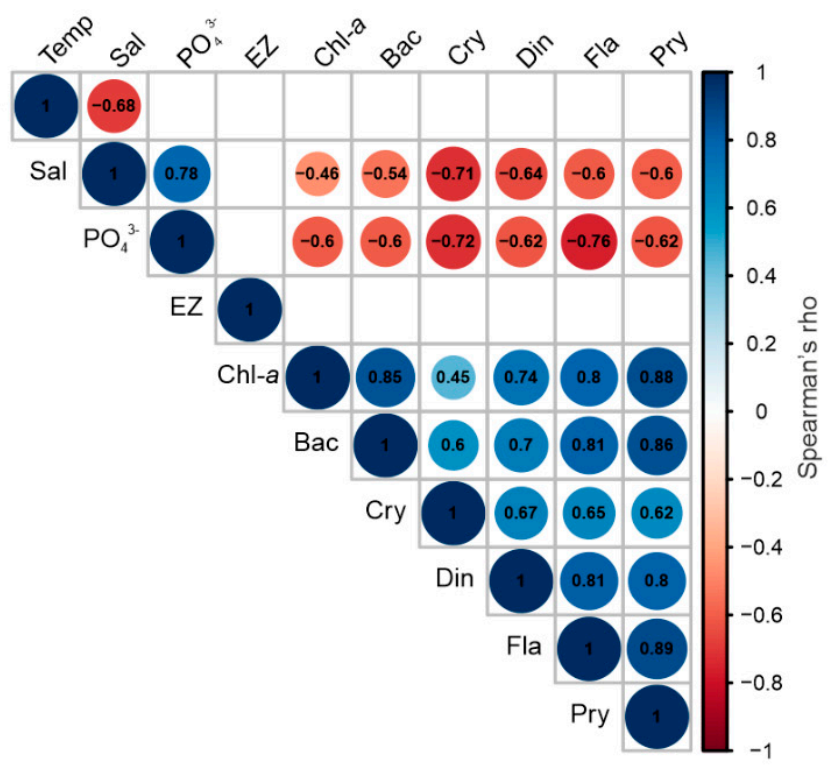

Figure 6. Correlation matrices (Spearman) among physical, chemical and biological variables: (a) the result of the analysis of relationships between all environmental data collected in the investigated period; $(\mathbf{b})$ correlations between all biological and selected environmental variables (in the case of the most strongly correlated physical and chemical variables (rho between 0.8 and $1.0(-0.8$ and -1.0$)$ ), only one parameter was included in the analysis). Blank spaces indicate a nonsignificant correlation defined by a $p$-value of $>0.05$. Variables: Temp (temperature), Sal (salinity), DIN (dissolved inorganic nutrients $\left.\left(\mathrm{NO}_{3}{ }^{-}+\mathrm{NO}_{2}{ }^{-}\right)\right), \mathrm{PO}_{4}{ }^{3-}$ (phosphate), $\mathrm{Si}(\mathrm{OH})_{4}$ (silicic acid), EZ (euphotic zone extension), Chla (chlorophyll-a), Bac (Bacillariophyceae), Cry (Cryptophyceae), Din (Dinophyceae), Fla (Flagellates indet.), Pry (Prymnesiophyceae). 


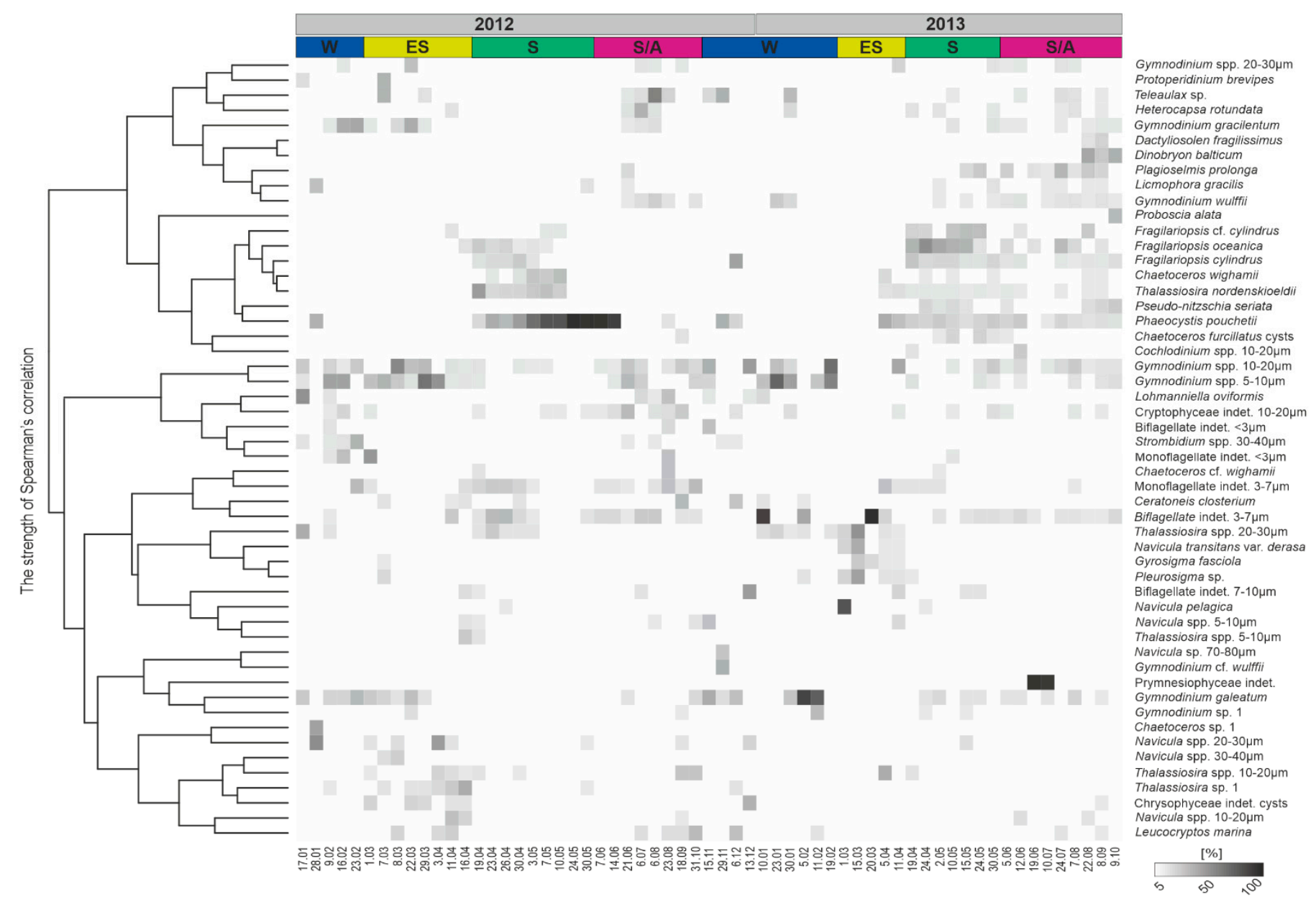

Figure 7. Heat map of taxa's contribution [\%] to the total abundance recorded at the IsA station in 2012 and 2013 . Due to frequent references to the results of 2012 in the discussion, the previous year's data are also shown. Abbreviations: W-winter, ES-early spring, S-spring, S/A-summer/autumn.

\section{Discussion}

High-resolution monitoring of planktonic protist annual cycles in the Arctic are scant, and thus our ability to link protistan phenology to environmental variability is limited [10,33]. Our studies of protists time series in Adventfjorden (a 2012-based study published in Kubiszyn et al. [13]; 2013 is presented herein) helped fill some of the identified knowledge gaps in the protistan plankton dynamics of the high Arctic fjord, as well as showed the fundamental variability in phenological events between the two consecutive years.

The winter community was similar to that in 2012, with low nano- and microplanktonic protist richness and abundance, as well as extremely low chlorophyll-a concentrations $\left(<0.05 \times 10^{8}\right.$ cells $\mathrm{m}^{-3}, 5-13$ taxa per sample, $<0.12 \mathrm{mg} \mathrm{m}^{-3}$, respectively), which can generally be taken as a common plankton feature for all West Spitsbergen fjords during the Polar Night ([34,35], own observations). Nanoplanktonic flagellates (especially Dinophyceae of the genus Gymnodinium) dominated during this period, which corresponds to previous studies in the waters of West and North Spitsbergen [18,36-41]. As is often the case with unarmoured cells, due to lack of characteristic morphological features and susceptibility to distortion by fixatives, many Gymnodinium taxa were identified only to the genus level with additional size class distinction [42]. This made it difficult to determine how many species overwinter in the water column. Certainly, due to the practically year-round presence of these dinoflagellates in the studied region and a significant share in the total protistan abundance, and potentially also in primary production, this genus deserves further research with the simultaneous use of molecular and microscopic tech- 
niques. Additionally, and in line with other studies, our results demonstrated that a very few primary producers (primarily Bacillariophyceae-Thalassiosira, Navicula) were present in Adventfjorden throughout the winter, most likely accidentally introduced into the water column from the bottom sediments as a result of strong vertical mixing (as evidenced by the presence of highly-siliceous benthic diatoms of size 70-100 $\mu \mathrm{m}$ ). Although primary production during winter/early spring in the area is estimated to be close to zero [10,43], also reflected in the very low chlorophyll- $a$ values (Figure 4c), phototrophic protists in the water column at this time is by no means a novel finding. Recent reports indicated that diatoms are generally well-adapted to the survival of the Polar Night (at the latitude of this study area $\left(78^{\circ} \mathrm{N}\right)$, the sun stays below the horizon for $\sim 4$ months, Figure 4 a) by sustaining an active photosynthetic apparatus for months in darkness, with taxon-specific survival traits $[41,44]$. This could allow them to become immediately active upon exposure to light and recover total photosynthetic activity within a short period. Although it is believed that this strategy gives Arctic diatoms a competitive advantage during the early spring, it does not necessarily imply that these survivalists dominate the final stages of the spring bloom $[34,44]$. Our two-year study clearly demonstrated that the late spring bloom stage was taxonomically different from the Bacillariophyceae population in the winter/early spring, indicating that these cells were likely not responsible for initiating blooms [13]. Additionally, the lack of typical spring bloom species during winter and early spring seems to exclude the possibility that bloom-initiating cells overwinter in the water column. Instead, our results support the overwintering of the spring bloom inoculum in a surface layer of marine sediments, as previously suggested, among others, by Hegseth et al. [45] and Brown et al. [46].

In Adventfjorden, the spring bloom initiated in both years in the second half of April (i.e., at the same time as in ice-free Kongsfjorden, [3]), indicating light availability (as a function of daylength and solar elevation) as the primary trigger initiating the spring blooms. As in 2012, the spring bloom progressed in an unstratified water column, promoting cell resuspension from the sea bottom to the surface. As a result, chlorophyll- $a$ and abundances showed exponential growth from late April to the end of May (a 100-fold increase in pigment content and order of magnitude higher numbers in relation to winter/early spring values). The mismatch between the highest chlorophyll- $a$ concentration (observed at the turn of April and May) and the highest abundance of nano- and microplanktonic protists (lasting throughout May) (Figure 4c), despite the relatively constant taxonomic composition during spring (Figure 4d), could have two reasons for causing this effect alone or combined. First, it could result from the domination of the pico- and smallest nanoplanktonic phytoflagellates in the early bloom, contributing to the total pigment content but not observable in microscopic examination or underestimated in numbers. The corresponding transition of pre-bloom communities toward autotrophic microbial eukaryotes of sizes 0.45 to $10 \mu \mathrm{m}$, dominated by the Arctic Micromonas ecotype (strain; 1-3 $\mu \mathrm{m}$ ), was previously reported for the IsA station by Marquard et al. [11]. Secondly, a high chlorophyll- $a$ concentration coinciding in time with lower protist numbers may indicate that the observed pigment content, at least in part, originated from macroalgae debris. Since the IsA station represents a highly dynamic and shallow ecosystem, the wind action may lead to the advection of macroalgal residues from ice-covered Isfjorden bays, where shallow water kelp forest zones are heavily affected by the ice scouring in winter and early spring [35]. Additionally, the wind-driven resuspension may cause an exchange of material between the sediment and the water column, including entrainment of benthic algae, which occasionally account for most of the chlorophyll found in the pelagic zone $[47,48]$. The spring community was dominated by Bacillariophyceae (mainly chain-formed Fragilariopsis, Thalassiosira nordenskioeldii, and, to a lesser extent, also Pseudo-nitzschia seriata) and haptophyte Phaeocystis pouchetii, commonly occurring at this time of the year in West Spitsbergen waters $[13,38,49]$ and other Arctic regions [50]. Noteworthy, the strict dominance of colonial P. pouchetii over Bacillariophyceae during the 2012 bloom was not seen in 2013. The possible explanation for this may be differences in win- 
tertime and spring AW inflow events to Adventfjorden between the two years. Previous research indicated that shifts in bloom timing and composition characterise years with intensive AW advection (as in the case of 2012), with an increased relative abundance of the P. pouchetii (possibly due to introduction of haptophytes by Atlantic advection; $[15,16,51]$ ). Even though Atlantic advection also took place in winter 2013, it was somewhat episodic (January-February) compared to the long-term AW dominance at the IsA station in 2012 (end of February to the end of April) and well before the spring bloom onset. In light of this, our results may be relevant to support the already proposed link between the timing and magnitude of $\mathrm{AW}$ inflow and the spring bloom composition. Naturally, in addition to biological advection along with the AW inflows, oceanic water may also provide an extra pool of nutrients to the West Spitsbergen fjords $[52,53]$ that could influence the succession of phytoplankton species during the spring bloom. According to Fragoso et al. [54], the relative presence of diatoms and Phaeocystis in the spring bloom of the Labrador Sea may be influenced by the pre-bloom $\mathrm{Si}^{*}$ concentrations $\left(\mathrm{Si}^{*}=\mathrm{Si}(\mathrm{OH})_{4}-\mathrm{NO}_{3}{ }^{-}\right)$, associated with the input of riverine and glacial meltwater enriched with silica. Since our dataset showed only slightly lower $\mathrm{Si}^{*}$ values in early spring 2013 than in the corresponding time in 2012, it is difficult to say whether these differences contributed to the Bacillariophyceae-dominated bloom presented in this study. In line with the expectations that a diatom-poor bloom in 2012 would probably also affect the following year's inoculum since fewer spores would be produced, Bacillariophyceae-dominated spring bloom in 2013 was in modest intensity (up to $1.49 \times 10^{8}$ cells m$^{-3}$, [3]). The development of spring bloom species was slightly different than in the previous year, starting with a mixture of T. nordenskioeldii and P. pouchetii, followed by Fragilariopsis cylindrus and F. oceanica, and P. seriata. It is worth to mention that the scarce portion of Chaetoceros during the bloom in 2013, to setae of which Phaeocystis usually attaches, should not have a negative effect on the Phaeocystis bloom since it has been proven that chains of Fragilariopsis (and pennate diatoms as general) also may serve as a substrate for the colonies development [55]. These communities exhausted surface nutrient concentrations by the end of May, followed by their almost complete depletion in the water column by June.

After the spring bloom, a change in the species composition of the fjord marked the entrance to the summer season. The nutrient-limited post-bloom period (June-October) was reflected both by the change in the qualitative structure and in the gradual decrease in total protist abundance, which was most likely the effect of nutrient depletion, glacial melting associated with high water column turbidity and stratification, as well as intensive grazing by zooplankton. The major contributors to the total abundance were Gymnodinium spp., Heterocapsa rotundata (both Dinophyceae), Plagioselmis prolonga, Teleaulax sp. (both Cryptophyceae), and other free-living, small cryptophytes and undetermined nanoflagellates, typical for summer West Spitsbergen water $[4,14,56,57]$. Commonly observed biflagellates (3-7 $\mu \mathrm{m}$ in size), at least some of which are motile morphotypes of P. pouchetii, characterised the termination of a Phaeocystis bloom ([58], Figure 7). Noteworthy, ciliates (mostly Strombidium genus, especially Strombidium sp. $2(30-40 \mu \mathrm{m}$; sensu BérardTherriault et al. [59]) and, to a lesser extent, also Laboea strobila, Mesodinium rubrum and Lohmanniella oviformis) were unexpectedly scarce at this time. Their little importance, both in terms of share in the total abundance (Supplementary File S1) and the period of occurrence (mostly at the turn of spring and summer), may have several causes. First and most likely, it can be attributed to the high predation by very numerous meroplankton and mesozooplankton [4]. Furthermore, it could result from high turbidity since filter-feeding ciliates may be deterred by the high loads of fine sediment associated with summer glacier melting. Mineral-organic aggregates can also attach to lorica (shell-like protective outer covering), thus increasing the specific gravity of cells, making it difficult to actively graze and increase the loss of cells from the euphotic zone/or mixed layer depth. The selective, negative effect of high sediment content on ciliates with a simultaneous high share of dinoflagellates during summer (analogous to the research presented herein) has already been demonstrated for Kongsfjorden waters, inter alia, by Kubiszyn et al. [55]. Both the previous and current 
results, therefore, indicate a high resistance of dinoflagellates to waters siltation, which probably results from a variety of their feeding behaviour and mechanisms, along with the widespread hetero- and mixotrophy (modes of nutrition of species identified in the study are included in the open-access Nordic Microalgae database, http:/ /nordicmicroalgae.org/ (accessed on 29 June 2021)). Another feature that distinguishes this season was the relatively high portion of the spring taxa in the community. The observed temporal resistance of spring taxa (previously reported in Isfjorden by Wẹsławski et al. [60]), associated with the commonly observed taxa in the West Svalbard fjords during summer (Kubiszyn et al. [13] and references therein), could be caused by several factors, i.e., (1) a strongly stratified water column that prevented cell sedimentation, (2) low microzooplankton pressure on primary producers that generally had more of a direct control on phytoplankton loss rates than mesozooplankton grazing [61], (3) resuspension of cells by currents and waves from a subtidal coastal site [62], or (4) a supply of cells from outside the fjord along with the advection of oceanic waters and/or sea ice.

Interestingly, on a short-term scale (two samplings in June and July with three weeks apart), the summer community was practically $100 \%$ dominated by indeterminate Prymnesiophyceae, most likely of genus Chrysochromulina, damaged or severely deformed by fixation. The massive growth of this taxon occurred soon after a significant reduction of the euphotic zone thickness in early June, which suggests that the fjord could experience substantial suspension matter loads with freshwater input from glacial rivers at this time that could bring Chrysochromulina-like species into the fjord. The latter return of the community to the state as it had presented before (in terms of species composition and abundance) additionally speaks for some disturbance factor that rapidly, temporarily rebuilt the structure of the community. Our results highlight salinity as a strong determinant of protist community composition while also demonstrating the importance of nutrient supply, where abundance generally decreased with increasing salinity and increased with nutrient depletion. However, it is certain that other abiotic factors are also important and can interact with or stand behind changes in salinity to influence protists communities (e.g., seawater turbidity; unfortunately, not included in the study). In other words, as Delpech et al. [63] documented for the structure of summer bacterial and archaeal communities of Isfjorden, reorganisation of protists community composition and functioning coinciding with gradients in salinity and nutrients (especially in melting season) could illustrate the significance of seasonal changes in terrestrial inputs.

Unfortunately, due to the shortened research period compared to the year-round 2012 study, we could not observe the entire phenological cycle with a return to the initial state by the end of the year (Figure 5). Nevertheless, even with less frequent sampling throughout the season, we managed to capture the transition into the autumn community from late August onwards (consisting of Dinobryon balticum, Dactyliosolen fragilissimus, and Proboscia alata), concomitant with the gradual decrease in light availability.

\section{Conclusions}

In the presented study, we generated a data set enabling us to accurately trace the protists phenology of Adventfjoren in the seasonal cycle (winter-autumn 2013) and referred the obtained results to analogous studies conducted throughout 2012. Although the general trend followed the classic annual paradigm [3], protists dynamics differed significantly between the years, as was proposed before for the more northerly located Kongsfjorden [15-17]. The most spectacular differences concerned the spring bloom which accounts for a substantial part of annual production, supports pelagic and benthic secondary production, and influences biogeochemical cycles, and, consequently, the summer/autumn communities. In contrast to the virtually completely Phaeocystis-dominated spring bloom in 2012, when AW dominated in the fjord, spring bloom in 2013 when local water prevailed was mainly composed of Bacillariophyceae (especially Fragilariopsis and Thalassiosira, and, in a lesser extent, also Pseudo-nitzschia). A high share of them persisted throughout the summer/autumn when they co-occurred with typical summer taxa (Dinophyceae 
and Cryptophyceae). Although the results do not allow us to prove mechanistic links between environmental variables and protists phenology, they suggest that the observed inter-annual variability in protist communities can be partially attributed to differences in AW inflow to the fjord, thus increasing the reliability of previously proposed scenarios for Kongsfjorden waters. Since the West Spitsbergen fjords' hydrography leads to a high level of unpredictability in recent years [64], with a pronounced trend of increasingly frequent winter and spring infusions of AW [65], we, therefore, concluded that it might be accompanied by increased inter-annual variability in protists phenology. While spring bloom's timing seems to be of light control in the ice-free waters and relatively constant between years (mid-April), these fluctuations will mainly manifest in species composition and abundance. Therefore, we would like to emphasise that each year should be treated individually in light of such high volatility, and any phenological patterns should be determined with great care. Similarly, short-term (usually summer) data should be interpreted in relation to traditional seasonal dynamics with high caution. Because our research clearly demonstrated that one or even two years of high-resolution monitoring is not enough to resolve the temporal variations of protist communities against the changing Arctic conditions, examination of annual cycles over many years is strongly required.

Supplementary Materials: The following is available online at https:/ /www.mdpi.com/article/10 .3390/w13141990/s1, File S1: Share (>75\%, “+++++"; >50\%, "++++"; >25\%, "+++"; >10\%, "++"; >5\%, "+"; $>1 \%$, "•") of taxa in the total abundance per cubic metre (averaged for the 5-60 m water column; in italics) in individual sampling days in 2013.

Author Contributions: A.M.D. analysed protist samples, processed and analysed biological/environmental data, prepared the original draft, including tables and figures; J.M.W. contributed to study conceptualisation; J.M.W.J. contributed to statistical analysis; S.K. analysed nutrients; A.V. collected samples, coordinated samples and data; T.G. acquired the funding, coordinated the project, organised sampling campaign, collected samples. All authors have read and agreed to the published version of the manuscript.

Funding: This study was funded by the National Science Centre, Poland, within the Let's Sea Project (2015/17/N/NZ8/01642), partially funded by ConocoPhillips and Lundin Petroleum through their Northern Area Programme and was published with the support of the Ministry of Science and Higher Education (W28/Svalbard/2019).

Institutional Review Board Statement: Not applicable.

Informed Consent Statement: Not applicable.

Data Availability Statement: The datasets generated for this study are available on request to the corresponding author.

Acknowledgments: We would like to thank the IsA 2013 sampling campaign participants for collecting the samples. We also wish to express our gratitude to Mikołaj Mazurkiewicz (IO PAN) for the discussion on statistical data analysis, and Piotr Konrad Dabrowski (IO PAN) for his continuous help and support. Finally, we thank the editor and the anonymous reviewers for their constructive comments, which helped us to improve the manuscript.

Conflicts of Interest: The authors declare no conflict of interest.

\section{References}

1. Fenchel, T. Ecology of Protozoa: The Biology of Free-Living Phagotropic Protists; Springer: Berlin/Heidelberg, Germany, 2013; ISBN 978-3-662-25981-8.

2. Ardyna, M.; Arrigo, K. Phytoplankton Dynamics in a Changing Arctic Ocean. Nat. Clim. Chang. 2020, 10. [CrossRef]

3. Hegseth, E.N.; Assmy, P.; Wiktor, J.M.; Wiktor, J.; Kristiansen, S.; Leu, E.; Tverberg, V.; Gabrielsen, T.M.; Skogseth, R.; Cottier, F. Phytoplankton Seasonal Dynamics in Kongsfjorden, Svalbard and the Adjacent Shelf. In The Ecosystem of Kongsfjorden, Svalbard; Hop, H., Wiencke, C., Eds.; Springer International Publishing: Cham, Switzerland, 2019; Volume 2, pp. 173-227. ISBN 978-3-319-46423-7. 
4. Szeligowska, M.; Trudnowska, E.; Boehnke, R.; Dabrowska, A.M.; Wiktor, J.M.; Sagan, S.; Błachowiak-Samołyk, K. Spatial Patterns of Particles and Plankton in the Warming Arctic Fjord (Isfjorden, West Spitsbergen) in Seven Consecutive Mid-Summers (2013-2019). Front. Mar. Sci. 2020, 7. [CrossRef]

5. Nilsen, F.; Cottier, F.; Skogseth, R.; Mattsson, S. Fjord-Shelf Exchanges Controlled by Ice and Brine Production: The Interannual Variation of Atlantic Water in Isfjorden, Svalbard. Cont. Shelf Res. 2008, 28, 1838-1853. [CrossRef]

6. Zajączkowski, M.; Włodarska-Kowalczuk, M. Dynamic Sedimentary Environments of an Arctic Glacier-Fed River Estuary (Adventfjorden, Svalbard). I. Flux, Deposition, and Sediment Dynamics. Estuar. Coast. Shelf Sci. 2007, 74, 285-296. [CrossRef]

7. McGovern, M.; Pavlov, A.K.; Deininger, A.; Granskog, M.A.; Leu, E.; Søreide, J.E.; Poste, A.E. Terrestrial Inputs Drive Seasonality in Organic Matter and Nutrient Biogeochemistry in a High Arctic Fjord System (Isfjorden, Svalbard). Front. Mar. Sci. 2020, 7. [CrossRef]

8. Skogseth, R.; Olivier, L.L.A.; Nilsen, F.; Falck, E.; Fraser, N.; Tverberg, V.; Ledang, A.B.; Vader, A.; Jonassen, M.O.; Søreide, J.; et al. Variability and Decadal Trends in the Isfjorden (Svalbard) Ocean Climate and Circulation-An Indicator for Climate Change in the European Arctic. Prog. Oceanogr. 2020, 187, 102394. [CrossRef]

9. Eilertsen, H.C.; Taasen, J.P.; WesIawski, J.M. Phytoplankton Studies in the Fjords of West Spitzbergen: Physical Environment and Production in Spring and Summer. J. Plankton Res. 1989, 11, 1245-1260. [CrossRef]

10. Rokkan Iversen, K.; Seuthe, L. Seasonal Microbial Processes in a High-Latitude Fjord (Kongsfjorden, Svalbard): I. Heterotrophic Bacteria, Picoplankton and Nanoflagellates. Polar Biol. 2011, 34, 731-749. [CrossRef]

11. Marquardt, M.; Vader, A.; Stübner, E.I.; Reigstad, M.; Gabrielsen, T.M. Strong Seasonality of Marine Microbial Eukaryotes in a High-Arctic Fjord (Isfjorden, in West Spitsbergen, Norway). Appl. Environ. Microbiol. 2016, 82, 1868-1880. [CrossRef]

12. Marquardt, M.; Skogseth, R.; Wiedmann, I.; Vader, A.; Reigstad, M.; Cottier, F.; Gabrielsen, T.M. Vertical Export of Marine Pelagic Protists in an Ice-Free High-Arctic Fjord (Adventfjorden, West Spitsbergen) throughout 2011-2012. Aquat. Microb. Ecol. 2019, 83, 65-82. [CrossRef]

13. Kubiszyn, A.M.; Wiktor, J.M.; Wiktor, J.M.; Griffiths, C.; Kristiansen, S.; Gabrielsen, T.M. The Annual Planktonic Protist Community Structure in an Ice-Free High Arctic Fjord (Adventfjorden, West Spitsbergen). J. Mar. Syst. $2017,169,61-72$. [CrossRef]

14. Szeligowska, M.; Trudnowska, E.; Boehnke, R.; Dąbrowska, A.M.; Dragańska-Deja, K.; Deja, K.; Darecki, M.; Błachowiak-Samołyk, K. The Interplay between Plankton and Particles in the Isfjorden Waters Influenced by Marine- and Land-Terminating Glaciers. Sci. Total Environ. 2021, 780, 146491. [CrossRef] [PubMed]

15. Hodal, H.; Falk-Petersen, S.; Hop, H.; Kristiansen, S.; Reigstad, M. Spring Bloom Dynamics in Kongsfjorden, Svalbard: Nutrients, Phytoplankton, Protozoans and Primary Production. Polar Biol. 2012, 35, 191-203. [CrossRef]

16. Hegseth, E.N.; Tverberg, V. Effect of Atlantic Water Inflow on Timing of the Phytoplankton Spring Bloom in a High Arctic Fjord (Kongsfjorden, Svalbard). J. Mar. Syst. 2013, 113, 94-105. [CrossRef]

17. Mayzaud, P.; Boutoute, M.; Noyon, M.; Narcy, F.; Gasparini, S. Lipid and Fatty Acids in Naturally Occurring Particulate Matter during Spring and Summer in a High Arctic Fjord (Kongsfjorden, Svalbard). Mar. Biol. 2013, 160, 383-398. [CrossRef]

18. Vader, A.; Marquardt, M.; Meshram, A.R.; Gabrielsen, T.M. Key Arctic Phototrophs Are Widespread in the Polar Night. Polar Biol. 2015, 38, 13-21. [CrossRef]

19. Stübner, E.I.; Søreide, J.E.; Reigstad, M.; Marquardt, M.; Blachowiak-Samolyk, K. Year-Round Meroplankton Dynamics in High-Arctic Svalbard. J. Plankton Res. 2016, 38, 522-536. [CrossRef]

20. Wiedmann, I.; Reigstad, M.; Marquardt, M.; Vader, A.; Gabrielsen, T.M. Seasonality of Vertical Flux and Sinking Particle Characteristics in an Ice-Free High Arctic Fjord-Different from Subarctic Fjords? J. Mar. Syst. 2016, 154, 192-205. [CrossRef]

21. Svendsen, H.; Beszczynska-Møller, A.; Hagen, J.O.; Lefauconnier, B.; Tverberg, V.; Gerland, S.; Ørbæk, J.B.; Bischof, K.; Papucci, C.; Zajaczkowski, M.; et al. The Physical Environment of Kongsfjorden-Krossfjorden, an Arctic Fjord System in Svalbard. Polar Res. 2002, 21, 133-166. [CrossRef]

22. Fraser, N.J.; Skogseth, R.; Nilsen, F.; Inall, M.E. Circulation and Exchange in a Broad Arctic Fjord Using Glider-Based Observations. Polar Res. 2018, 37, 1485417. [CrossRef]

23. Saloranta, T.M.; Svendsen, H. Across the Arctic Front West of Spitsbergen: High-Resolution CTD Sections from 1998-2000. Polar Res. 2001, 20, 177-184. [CrossRef]

24. Muckenhuber, S.; Nilsen, F.; Korosov, A.; Sandven, S. Sea Ice Cover in Isfjorden and Hornsund, Svalbard (2000-2014) from Remote Sensing Data. Cryosphere 2016, 10, 149-158. [CrossRef]

25. Dobrzyn, P.; Keck, A.; Tatur, A. Sedimentation of Chlorophylls in an Arctic Fjord under Freshwater Discharge. Hydrobiologia 2005, 532, 1-8. [CrossRef]

26. Mamaev, O.I. TS-Analiz Vod Mirovogo Okeana; Gidrometeoizdat: Leningrad, Russia, 1970.

27. Holm-Hansen, O.; Riemann, B. Chlorophyll a Determination: Improvements in Methodology. Oikos 1978, 30, 438-447. [CrossRef]

28. Utermöhl, H. Zur Vervollkommnung der quantitativen Phytoplankton-Methodik: Mit 1 Tabelle und 15 abbildungen im Text und auf 1 Tafel. SIL Commun. 1953-1996 1958, 9, 1-38. [CrossRef]

29. Edler, L. Recommendations on Methods for Marine Biological Studies in the Baltic Sea. Phytoplankton and Chlorophyll. Publ. Balt. Mar. Biol. BMB Swed. 1979, 27. Available online: https://helcom.fi/wp-content/uploads/2019/10/BSEP27D.pdf (accessed on 29 June 2021). 
30. R Core Team. R: A Language and Environment for Statistical Computing 2017. Available online: https://www.r-project.org/ (accessed on 20 June 2021).

31. Oksanen, J.; Blanchet, F.G.; Friendly, M.; Kindt, R.; Legendre, P.; McGlin, D.; Minchin, P.; O'Hara, R.; Simpson, G.; Solymos, P.; et al. Vegan: Community Ecology Package. R Package Version 2.4-3. 2017. Available online: https://www.scirp.org/(S(i4 3dyn45teexjx455q1t3d2q))/reference/ReferencesPapers.aspx?ReferenceID=1778707 (accessed on 1 January 2016).

32. Redfield, A.C. On the Proportions of Organic Derivatives in Sea Water and Their Relation to the Composition of Plankton; University Press of Liverpool: Liverpool, UK, 1934; pp. 176-192.

33. Rózańska, M.; Gosselin, M.; Poulin, M.; Wiktor, J.M.; Michel, C. Influence of Environmental Factors on the Development of Bottom Ice Protist Communities during the Winter-Spring Transition. Mar. Ecol. Prog. Ser. 2009, 386, 43-59. [CrossRef]

34. Berge, J.; Daase, M.; Renaud, P.E.; Ambrose, W.G.; Darnis, G.; Last, K.S.; Leu, E.; Cohen, J.H.; Johnsen, G.; Moline, M.A.; et al. Unexpected Levels of Biological Activity during the Polar Night Offer New Perspectives on a Warming Arctic. Curr. Biol. 2015, 25, 2555-2561. [CrossRef]

35. Berge, J.; Johnsen, G.; Cohen, J.H. Polar Night Marine Ecology: Life and Light in the Dead of Night; Springer Nature: Basingstoke, UK, 2020; ISBN 978-3-030-33208-2.

36. Weslawski, J.M.; Kwasniewski, S.; Wiktor, J. Winter in a Svalbard Fiord Ecosystem. Arctic 1991, 44, 115-123. [CrossRef]

37. Zhang, Q.; Gradinger, R.; Spindler, M. Dark Survival of Marine Microalgae in the High Arctic (Greenland Sea). Polarforschung 1998, 65, 111-116.

38. Wiktor, J. Early Spring Microplankton Development under Fast Ice Covered Fjords of Svalbard, Arctic. Oceanologia 1999, 41, 51-72.

39. Eilertsen, H.C.; Degerlund, M. Phytoplankton and Light during the Northern High-Latitude Winter. J. Plankton Res. 2010, 32, 899-912. [CrossRef]

40. Błachowiak-Samołyk, K.; Wiktor, J.M.; Hegseth, E.N.; Wold, A.; Falk-Petersen, S.; Kubiszyn, A.M. Winter Tales: The Dark Side of Planktonic Life. Polar Biol. 2015, 38, 23-36. [CrossRef]

41. Kvernvik, A.C.; Hoppe, C.J.M.; Lawrenz, E.; Prášil, O.; Greenacre, M.; Wiktor, J.M.; Leu, E. Fast Reactivation of Photosynthesis in Arctic Phytoplankton during the Polar Night1. J. Phycol. 2018, 54, 461-470. [CrossRef] [PubMed]

42. Kubiszyn, A.M.; Wiktor, J.M. The Gymnodinium and Gyrodinium (Dinoflagellata: Gymnodiniaceae) of the West Spitsbergen Waters (1999-2010): Biodiversity and Morphological Description of Unidentified Species. Polar Biol. 2016, 39, $1739-1747$. [CrossRef]

43. Seuthe, L.; Rokkan Iversen, K.; Narcy, F. Microbial Processes in a High-Latitude Fjord (Kongsfjorden, Svalbard): II. Ciliates and Dinoflagellates. Polar Biol. 2011, 34, 751-766. [CrossRef]

44. van de Poll, W.H.; van de Abdullah, E.; Visser, R.J.W.; Fischer, P.; Buma, A.G.J. Taxon-Specific Dark Survival of Diatoms and Flagellates Affects Arctic Phytoplankton Composition during the Polar Night and Early Spring. Limnol. Oceanogr. 2020, 65, 903-914. [CrossRef]

45. Hegseth, E.N.; Svendsen, H.; von Quillfeldt, C.H. Phytoplankton in fjords and coastal waters of northern Norway: Environmental conditions and dynamics of the spring bloom. In Ecology of Fjords and Coastal Waters; Elsevier: Amsterdam, The Netherlands, 1995; pp. 45-72.

46. Brown, T.A.; Hegseth, E.N.; Belt, S.T. A Biomarker-Based Investigation of the Mid-Winter Ecosystem in Rijpfjorden, Svalbard. Polar Biol. 2015, 38, 37-50. [CrossRef]

47. Sañé, E.; Valente, A.; Fatela, F.; Cabral, M.C.; Beltrán, C.; Drago, T. Assessment of Sedimentary Pigments and Phytoplankton Determined by CHEMTAX Analysis as Biomarkers of Unusual Upwelling Conditions in Summer 2014 off the SE Coast of Algarve. J. Sea Res. 2019, 146, 33-45. [CrossRef]

48. Conde, D.; Bonilla, S.; Aubriot, L.; de León, R.; Pintos, W. Comparison of the areal amount of chlorophyll a of planktonic and attached microalgae in a shallow coastal lagoon. In Shallow Lakes '98; Walz, N., Nixdorf, B., Eds.; Springer: Dordrecht, The Netherlands, 1999; pp. 285-291. ISBN 978-90-481-5370-1.

49. Zajączkowski, M.; Nygård, H.; Hegseth, E.N.; Berge, J. Vertical Flux of Particulate Matter in an Arctic Fjord: The Case of Lack of the Sea-Ice Cover in Adventfjorden 2006-2007. Polar Biol. 2010, 33, 223-239. [CrossRef]

50. von Quillfeldt, C.H. Common Diatom Species in Arctic Spring Blooms: Their Distribution and Abundance. Bot. Mar. 2000, 43, 499-516. [CrossRef]

51. van de Poll, W.H.; Maat, D.S.; Fischer, P.; Rozema, P.D.; Daly, O.B.; Koppelle, S.; Visser, R.J.W.; Buma, A.G.J. Atlantic Advection Driven Changes in Glacial Meltwater: Effects on Phytoplankton Chlorophyll-a and Taxonomic Composition in Kongsfjorden, Spitsbergen. Front. Mar. Sci. 2016, 3. [CrossRef]

52. Vernet, M.; Ellingsen, I.H.; Seuthe, L.; Slagstad, D.; Cape, M.R.; Matrai, P.A. Influence of Phytoplankton Advection on the Productivity Along the Atlantic Water Inflow to the Arctic Ocean. Front. Mar. Sci. 2019, 6. [CrossRef]

53. Menze, S.; Ingvaldsen, R.B.; Nikolopoulos, A.; Hattermann, T.; Albretsen, J.; Gjøsæter, H. Productive Detours—Atlantic Water Inflow and Acoustic Backscatter in the Major Troughs along the Svalbard Shelf. Prog. Oceanogr. 2020, 188, 102447. [CrossRef]

54. Fragoso, G.M.; Poulton, A.J.; Yashayaev, I.M.; Head, E.J.H.; Stinchcombe, M.C.; Purdie, D.A. Biogeographical Patterns and Environmental Controls of Phytoplankton Communities from Contrasting Hydrographical Zones of the Labrador Sea. Prog. Oceanogr. 2016, 141, 212-226. [CrossRef] 
55. Sazhin, A.F.; Artigas, L.F.; Nejstgaard, J.C.; Frischer, M.E. The colonization of two Phaeocystis species (Prymnesiophyceae) by pennate diatoms and other protists: A significant contribution to colony biomass. In Phaeocystis, Major Link in the Biogeochemical Cycling of Climate-Relevant Elements; van Leeuwe, M.A., Stefels, J., Belviso, S., Lancelot, C., Verity, P.G., Gieskes, W.W.C., Eds.; Springer: Dordrecht, The Netherlands, 2007; pp. 137-145. ISBN 978-1-4020-6214-8.

56. Piwosz, K.; Walkusz, W.; Hapter, R.; Wieczorek, P.; Hop, H.; Wiktor, J. Comparison of Productivity and Phytoplankton in a Warm (Kongsfjorden) and a Cold (Hornsund) Spitsbergen Fjord in Mid-Summer 2002. Polar Biol. 2009, 32, 549-559. [CrossRef]

57. Kubiszyn, A.M.; Piwosz, K.; Wiktor, J.M., Jr.; Wiktor, J.M. The Effect of Inter-Annual Atlantic Water Inflow Variability on the Planktonic Protist Community Structure in the West Spitsbergen Waters during the Summer. J. Plankton Res. 2014, 36, $1190-1203$. [CrossRef]

58. Rousseau, V.; Vaulot, D.; Casotti, R.; Cariou, V.; Lenz, J.; Gunkel, J.; Baumann, M. The Life Cycle of Phaeocystis (Prymnesiophycaea): Evidence and Hypotheses. J. Mar. Syst. 1994, 5, 23-39. [CrossRef]

59. Bérard-Therriault, L.; Poulin, M.; Bossé, L. Guide D'identification du Phytoplancton Marin de L'estuaire et du Golfe du Saint-Laurent: Incluant Également Certains Protozoaires; NRC Research Press: Ottawa, ON, Canada, 1999; ISBN 978-0-660-96057-9.

60. Weslawski, J.M.; Kwasniewski, S.; Swerpel, S.; Wiktor, J.; Zajaczkowski, M.; Ostrowski, M.; Siwecki, R. Summer environmental survey of Gipsvika, Svalbard. In; Environmental Atlas Gipsdalen, Svalbard. Environ. Atlas Gipsdalen Svalbard 1990, 2, $111-131$.

61. Friedland, K.D.; Record, N.R.; Asch, R.G.; Kristiansen, T.; Saba, V.S.; Drinkwater, K.F.; Henson, S.; Leaf, R.T.; Morse, R.E.; Johns, D.G.; et al. Seasonal Phytoplankton Blooms in the North Atlantic Linked to the Overwintering Strategies of Copepods. Elem. Sci. Anthr. 2016, 4. [CrossRef]

62. Shimeta, J.; Amos, C.L.; Beaulieu, S.E.; Ashiru, O.M. Sequential Resuspension of Protists by Accelerating Tidal Flow: Implications for Community Structure in the Benthic Boundary Layer. Limnol. Oceanogr. 2002, 47, 1152-1164. [CrossRef]

63. Delpech, L.-M.; Vonnahme, T.R.; McGovern, M.; Gradinger, R.; Præbel, K.; Poste, A.E. Terrestrial Inputs Shape Coastal Bacterial and Archaeal Communities in a High Arctic Fjord (Isfjorden, Svalbard). Front. Microbiol. 2021, 12. [CrossRef] [PubMed]

64. Tverberg, V.; Skogseth, R.; Cottier, F.; Sundfjord, A.; Walczowski, W.; Inall, M.E.; Falck, E.; Pavlova, O.; Nilsen, F. The Kongsfjorden Transect: Seasonal and Inter-annual Variability in Hydrography. In The Ecosystem of Kongsfjorden, Svalbard; Hop, H., Wiencke, C., Eds.; Springer International Publishing: Cham, Switerland, 2019; pp. 49-104. ISBN 978-3-319-46425-1.

65. Goszczko, I.; Ingvaldsen, R.B.; Onarheim, I.H. Wind-Driven Cross-Shelf Exchange-West Spitsbergen Current as a Source of Heat and Salt for the Adjacent Shelf in Arctic Winters. J. Geophys. Res. Ocean. 2018, 123, 2668-2696. [CrossRef] 